\title{
Why are dividends disappearing? An empirical analysis*
}

\author{
Malcolm Baker \\ Harvard Business School and NBER \\ $\underline{\text { mbaker@hbs.edu }}$ \\ Jeffrey Wurgler \\ NYU Stern School of Business \\ jwurgler@stern.nyu.edu
}

November 14, 2002

\begin{abstract}
We investigate the causes of time-series fluctuations in the propensity to pay dividends, including the post-1978 decline documented by Fama and French (2001). We consider explanations based on fluctuations in dividend clienteles, agency problems, information asymmetries, executive stock options, catering incentives, tax code awareness, and short-lived idiosyncratic factors. To evaluate these explanations, we conduct three styles of analysis. First, we count and classify influences on the propensity to pay that were noted in the financial press. Second, we examine time-series relationships between the propensity to pay and proxies for the driving influences in the candidate explanations. Third, we assess whether the candidate explanations are theoretically compatible with related time-series patterns involving dividend policy. Overall, the results are most consistent with the catering explanation. Notably, catering incentives, as measured by the stock market "dividend premium," roughly line up with the four trends in the propensity to pay between 1963 and 2000 and are able to account for the observed magnitude of the post-1978 decline. There is also evidence that idiosyncratic factors, including the Nixon-era dividend controls and the recent growth in options, affected the propensity to pay in specific periods.
\end{abstract}

\footnotetext{
* We thank Ryan Taliaferro for research assistance. We thank Raj Aggarwal, David Backus, Brian Hall, Holger Mueller, Kevin Murphy, Lasse Pedersen, and seminar participants at Dartmouth, NYU, and the University of Florida for helpful comments. Baker gratefully acknowledges financial support from the Division of Research of the Harvard Business School.
} 


\section{Introduction}

In an important paper, Fama and French (2001) document a major shift in dividend policy. In $1978,67 \%$ of their Compustat sample pays dividends. But by 1999 , only $21 \%$ pays dividends. They trace part of this decline to a change in the sample. In recent years, more firms have low profits and high growth opportunities and thus would not be expected to pay dividends. However, even after accounting for this composition effect, they find a large decline in the residual "propensity to pay dividends." In this sense, dividends are disappearing.

Although this post-1978 disappearance has understandably received the most attention, it is important to realize that dividends have disappeared and reappeared before. In fact, since 1963 there have been four distinct trends in the propensity to pay dividends. These earlier cycles are illustrated in Figure 1, where we apply the Fama and French methodology for estimating the propensity to pay to the earlier Compustat data.

The top panels in the figure show the actual percentage of the sample that pays dividends in each year. They also show the percentage of firms that are expected to be payers, given prevailing firm characteristics. ${ }^{1}$ The propensity to pay dividends is defined as the difference between the actual percentage and the expected, and it plotted in the middle panels. The four distinct trends are apparent. There is an increase in the propensity to pay from 1963 through 1966-68 (depending on how exactly one measures PTP), a decrease until roughly 1972-74, a rebound through 1977, and then the decrease through the end of the sample. Each of these trends involves hundreds if not thousands of firms.

\footnotetext{
${ }^{1}$ Readers unfamiliar with their methodology should refer to Appendix 1. In brief, Fama and French fit a firm-level logit model of dividend payment over 1963-1977, and then evaluate this fixed model at the characteristics that prevail in a given year in order to estimate the expected percentage of payers for that year.
} 
Fama and French present the fluctuations in the propensity to pay dividends as a puzzle to be explained. In this paper, we attempt to shed light on their cause (or causes) by conducting a comprehensive empirical analysis. We consider six general candidate explanations. Each one, by necessity, posits a time-varying influence on dividends that is separate from firm and economic characteristics. In addition to these general explanations, we stay open to the possibility that at specific points in time, idiosyncratic influences played cameo roles.

Our six general candidate explanations are as follows. Explanations based on (1) agency costs or (2) asymmetric information propose that the nature of contracting changes over time, requiring changes in dividend policy. Explanations that view dividends as a response to investor demand include (3) clientele equilibrium theories in which changes in dividends are closely tied to changes in the size of dividend clienteles, and the related (4) catering theory in which they are influenced by changes in the relative stock prices of dividend payers and nonpayers. We also consider the possibility that variation in the use of (5) executive stock option compensation may have created a bias against paying dividends, and the notion that (6) it has simply taken time for managers to appreciate the tax disadvantages of dividends. Fama and French suggest some of these hypotheses in their conclusion. Others are drawn from recent research, or from traditional theories of dividends. To be comprehensive, we consider as many explanations as possible. And because we are not aware of any single, definitive empirical test, we evaluate them from as many perspectives as possible.

Our empirical analysis begins with a review of historical New York Times articles about dividends. This allows us to establish context, and to flag any institutional changes that financial writers linked to dividend policy. It also allows us to verify that our list of general candidate explanations is complete, by seeing whether the media makes reference to some pervasive 
influence that falls outside their scope. We start by reviewing the fifteen hundred abstracts for articles that appear between 1969 and 2001 and mention dividends in some fashion. From these abstracts we identify one hundred articles which, when read in their full text, allow us to catalog specific references to non-characteristics influences on dividend policy. We classify each of those references according to which of our candidate explanations that it most nearly invokes. We also take note of references to idiosyncratic institutional changes.

Under the working assumption that sophisticated financial writers will take note of the pervasive influences on dividends, this classification also allows for a rough horse race for our candidate explanations. That is, we find that the Times makes numerous references to tax-based clienteles, catering to investor sentiment for dividends, and slow learning about taxes. In contrast, our other candidate theories receive few media citations, however oblique. Of course, this style of analysis has obvious limitations. It is most useful when considered in conjunction with other approaches.

We then proceed to a standard time series analysis. We assemble proxies for tax- and transaction cost-based dividend clienteles, asymmetric information, executive stock options, and catering incentives. Then we try to match these variables up with the propensity to pay, visually and through regression specifications. The results are intriguing. We can visually match most of our proxies up with at least one and sometimes two of the time trends in the propensity to pay, probably just by chance in some cases. But our proxy for catering incentives, the dividend premium variable from Baker and Wurgler (2002), lines up with all four trends in the propensity to pay in Figure 1. This is our most striking finding. The propensity to pay increases when the dividend premium is positive, and declines when it is negative, as catering predicts. 
In fact, the dividend premium variable can, as an empirical matter, solve the disappearing dividends puzzle (the post-1978 decline) in the particular sense that it is posed by Fama and French. In other words, if the propensity to pay is fit to the dividend premium in the early years of the sample, and then this regression model is used to make an out-of-sample forecast for 1978 and beyond, then the forecast fits well with the actual propensity to pay. No unexplained decline remains. This is our second most striking finding.

Our final style of analysis is a discussion of the extent to which our candidate explanations can incorporate, in principle, other time-series patterns in the dividend data. In particular, DeAngelo, DeAngelo, and Skinner (2002) find that the firms that paid particularly small dividends were the most likely to omit them in recent years; Bagwell and Shoven (1989) and Grullon and Michaely (2002) document that the propensity to repurchase has increased even as the propensity to pay dividends has declined; and results in Baker and Wurgler (2002) suggest that changes in the propensity to pay dividends will be inversely related to the future relative stock returns of payers and nonpayers, which we confirm. We focus on these three patterns because they do not involve firm characteristics in any obvious way, and so would seem likely to be caused by the same forces that influence the propensity to pay. The capacity to incorporate them, in theory, therefore represents another type of "out-of-sample" test for our candidate explanations. Our discussion of these patterns is detailed and hard to summarize, but points us to the conclusion that a catering explanation requires the least amount of theoretical stretching to incorporate all three of these patterns.

There is reason to believe that a handful of other forces have played cameo roles at various times. For example, there is circumstantial evidence that Nixon's moral suasions against dividend growth had some effect between 1971 and 1974 - this influence on dividends was often 
cited by the Times, and this is the one period where the propensity to pay declines even though the dividend premium was positive. In addition, the results of Fenn and Liang (2001) and Grullon and Michaely (2002) strongly suggest that stock options and repurchases have propagated the post-1978 disappearance, although we can find no evidence that these factors initiated that particular decline. We end the paper with a highly stylized narrative of the forces that seem to drive the propensity to pay between 1963 and 2000. This draws our analysis together into a useful summary, and represents our answer to the question posed in the title.

The paper proceeds as follows. Section II outlines our candidate explanations. Section III reviews New York Times references to non-characteristics influences on dividends. Section IV documents time series relationships between the propensity to pay and various proxy variables. Section $\mathrm{V}$ discusses the ability of the candidate explanations to incorporate other noncharacteristics trends in the data. Section VI summarizes the analysis.

\section{Candidate explanations}

Our goal is to uncover the economic forces behind the trends in Figure 1. To get started, we develop a list of potential explanations based on existing theories of dividends. Roughly speaking, this leads to one entry per major theory of dividends. The common theme is that time variation in the propensity to pay is driven by corresponding variation in whatever underlying imperfection or inefficiency that the theory uses to motivate dividends.

Our focus on underlying economic forces means that, for example, we do not view "share repurchases" as a candidate explanation. Variation in market imperfections can induce both an increase in repurchases and a decrease in dividends, in which case an increase in repurchases would not be a meaningful economic "cause" of a decrease in dividends. Instead, the interesting 
question becomes what imperfection has changed to induce both trends. ${ }^{2}$ With this perspective in mind, we discuss trends in repurchases in section V.B.

Table 1 summarizes the six general explanations that we consider. The list includes the most prominent of the non-characteristics influences on dividends suggested in the literature, including the hypotheses offered in the conclusion of Fama and French (2001). It also includes some less formal theories suggested by recent work. Where possible, we state the explanations in a general form so that they can encompass institutional changes, such as tax code changes. Nevertheless, episodes such as the Nixon-era controls are a reminder that some idiosyncratic events will inevitably fall outside their scope. Such events are not listed in Table 1 because they are not general explanations, but they still need to be accounted for when studying specific eras. (In Section III, we review historical articles in the financial press in part to catalog such events.) We outline each candidate below.

\section{A. Agency}

Easterbrook (1984) views dividends as a corporate governance device that helps to keep managers close to the capital markets. In a similar spirit, Jensen (1986) prefers debt because it provides less discretion. Under this view, dividends could be disappearing (for example) because more effective governance mechanisms have appeared as substitutes. ${ }^{3}$ Jensen (1989), Kaplan (1997) and Holmstrom and Kaplan (2001) argue that U.S. corporate governance institutions have

\footnotetext{
${ }^{2}$ Grullon and Michaely (2002) suggest that SEC Rule 10b-18, which defined a safe harbor for open market repurchases and was introduced in 1983, represents an exogenous institutional change that may have influenced both dividend and repurchase trends. Figure 1 shows that the latest trend in dividend payment was already well underway by 1983, however, so "Rule 10b-18" cannot be a general candidate explanation for variations in the propensity to pay, or even this last trend. Rather, we view it as one of several interesting institutional shifts to keep in mind when studying particular periods in the data.

${ }^{3}$ Note that time variation in the level of free cash flow itself, holding governance constant, is not an explanation for time varying propensity to pay. Free cash flow is a firm characteristic, closely accounted for in the Fama and French (2001) firm-level model of dividend payment (through the market-to-book and profitability terms). Changes in the level of free cash flow would not directly affect the propensity to pay. What is required is some change in the contracting environment that is separate from firm or economic conditions.
} 
indeed changed substantially over the past two decades, generally for the better. While the recent wave of corporate scandals indicates that the system is still very far from perfect, perhaps these changes have generally reduced the need to control agency problems through dividends.

\section{B. Information asymmetry}

Ross (1977), Battacharya (1979), John and Williams (1985), and Miller and Rock (1985), among others, propose that managers use dividends as signals of profitability. In some models, the tax disadvantage of dividends provides the necessary cost of signaling; in others, the cost is foregone investment opportunities. These models predict that dividends would be used less often (for example) if the information gap between managers and investors has narrowed, or if substitute signaling mechanisms have become more effective. More specifically, information gaps may have been narrowed by information technology, or by the emergence of institutional investors with stronger incentives to gather information. Amihud and Li (2002) find that the average announcement effect of dividend changes has decreased over the past few decades and attribute this to increased stock ownership by institutions.

\section{C. $\quad$ Stock options}

When executives hold stock options that are not dividend protected, they have a personal incentive not to pay dividends, as pointed out by Lambert, Lanen, and Larcker (1989). ${ }^{4}$ Lambert et al., Jolls (1998), Weisbenner (1999), Fenn and Liang (2001), and Kahle (2002) find that stock options are indeed associated with lower dividends and higher repurchases. Given the recent explosion in option compensation documented by Yermack (1995) and Hall and Liebman (1997), these results point to executive options as a candidate for at least the most recent trend in the propensity to pay.

\footnotetext{
${ }^{4}$ Of course, the net incentive is ambiguous if paying dividends increases share price for some other reason, for example through signaling.
} 


\section{Clientele equilibrium}

A disappearance in dividends could also reflect a decline in investor demand for dividends per se. The clientele equilibrium theory starts from the observation that some institutional imperfection causes some investor clienteles to rationally demand dividends. Changes in this imperfection cause changes in the relative demands of pro- and anti-dividend clienteles, which in turn induce changes in the supply of dividends in equilibrium. According to the vision outlined in Miller and Modigliani (1961) and articulated more fully by Black and Scholes (1974), changes in demand are matched closely by changes in supply so that all clienteles are kept equally satisfied on the margin. Thus, competition among firms maintains a Miller (1977)-style equilibrium in which a nontrivial premium on shares with a particular dividend policy never arises. Corporate finance textbooks focus on the prescriptive implication of the clientele equilibrium view, that dividend policy is relevant in the aggregate but not at the firm level.

Miller and Modigliani and Black and Scholes identify several types of imperfections that can lead to dividend clienteles. Clienteles can arise for tax reasons. For example, dividends are tax advantaged for taxable corporations, but tax disadvantaged for most individuals. Transaction costs can motivate clienteles when some investors (e.g., retirees) use shareholdings to finance ongoing consumption - the transaction costs of making homemade dividends every quarter might lead them to prefer shares that just send liquidity in the mail. Institutional investment constraints can also lead to clienteles. Endowed institutions that by charter can spend only from the income component of returns, and institutional investors for whom dividend-paying stocks 
are easier to defend as "prudent" holdings to an investment committee, are examples. ${ }^{5}$ In summary, the clientele equilibrium view would attribute a decline in the supply of dividends (for example) to a decline in clientele demand, and further would predict that a nontrivial dividend premium never emerges.

\section{E. Catering}

The catering theory of Baker and Wurgler (2002) offers a second demand-based explanation for dividends. The theory argues that in inefficient stock markets, investor demand can at times create a significant gap between the stock prices of payers and (otherwise similar) nonpayers. This demand may come either from the rational clienteles enumerated above, or from investor sentiment for dividends versus capital gains. In the catering theory, managers rationally cater to this demand, paying dividends when dividend-paying shares are at a premium and not paying when dividend payers are discounted. ${ }^{6}$ Empirically, this theory would attribute a disappearance of dividends to a sustained stock market discount on dividend payers.

\section{F. $\quad$ Slow learning about taxes}

Our last hypothesis is that managers have been slow to learn the tax disadvantage of paying cash dividends. As their awareness has grown, they have reduced their propensity to pay dividends, presumably in favor of more lightly taxed repurchases, retained earnings, or cashfinanced acquisitions. In this spirit, Grinblatt and Titman (1998, p. 530) suggest that managers have been "simply wrong" to have paid tax-disadvantaged dividends instead of repurchase for so

\footnotetext{
${ }^{5}$ Del Guercio (1996) and Brav and Heaton (1998) study institutional investor clienteles induced by prudent man rules. Lewellen, Stanley, Lease, and Schlarbaum (1978) and Dhaliwal, Erickson, and Trezevant (1999) document tax clienteles. Lewellen et al. also find evidence of transaction cost clienteles among individual shareholders.

${ }^{6}$ Note that when demand for dividends comes from rational clienteles, the catering theory is simply a disequilibrium or inefficient markets version of the clientele equilibrium theory.
} 
long. Bagwell and Shoven (1989) propose that slow learning about the IRS treatment of repurchases may explain why they did not emerge earlier.

\section{News accounts of non-characteristics influences on dividends}

With these candidate explanations in mind, our first style of analysis is a review of historical New York Times articles that contain some discussion of dividends, whether in the context of a single firm or more generally. Given our focus on the propensity to pay, we are specifically interested in articles that make reference to some non-characteristics influence on dividends, as opposed to firm or economic fundamentals that by definition cannot be driving the trends that interest us.

This type of analysis is unconventional, but it serves a number of useful purposes. Most important, it allows us to catalog the major institutional changes that a sophisticated set of market observers connected to dividends. This helps us to determine whether the candidate explanations in Table 1 can be viewed as comprehensive. Along the way, it also provides an initial sort of reality check for the candidate explanations, by revealing which of them are and are not cited by financial writers. Finally, by keeping track of the dates at which references are clustered, we can get a sense of whether different forces were viewed as important at different times, or whether a single force was seen to be driving multiple trends.

\section{A. News sample}

We use the database search engine Factiva to identify all New York Times articles published between January 1, 1969 (when Factiva coverage begins) and December 31, 2001 that 
contain "dividend" or "dividends" at least twice in the abstract. ${ }^{7}$ This leads to an initial sample of 1,567 unique articles to inspect more closely. We read the abstract of each of these articles to determine whether it may contain some discussion of an influence on dividends that goes beyond firm characteristics. Most articles do not. For example, connecting dividend policy to profitability, "Wurlitzer Co. directors announce that dividend customarily paid ... will be omitted because of unprofitable operation results" (1/26/1974); or to investment opportunities, "Ford Motor Co., citing slump in auto industry, says it will not pay dividend ... says it must conserve cash resources so it can continue development and introduction of new products" (1/15/1982). Ultimately, 103 of the initial 1,567 abstracts suggest that the article may contain some useful analysis or commentary. The elimination of 1,464 abstracts is described in more detail in Appendix 2. For each of the 103 articles in the final sample, we read the full text from the New York Times archives.

\section{B. Classifying references}

The 103 articles in our final sample turn out to contain 95 specific references to a noncharacteristics based mechanism that, according to one of our theories or through a separate channel, might have affected dividends. (A few articles contain more than one such reference, while others turn out to contain none, despite what is suggested in their abstract.) Although our initial search criterion required "dividend" to appear at least twice in the abstract, only 44 of these 95 references explicitly link dividend policy to the proposed mechanism. The 95 references are listed in Table A and summarized in Table 2. We classify each reference according to which explanation for changing propensity to pay that it most closely invokes.

\footnotetext{
${ }^{7}$ The search engine for historical Wall Street Journal articles was not sufficiently precise. For example, one cannot exclude advertisements. This causes thousands of false "hits" and makes the analysis unmanageable. In any case, it seems reasonable to assume that any truly significant influence on dividends would be noted in the Times.
} 
Some examples will illustrate the classification process. The following quotation makes reference to investor sentiment for dividends, a mechanism unique to the catering theory, but it does not link through to dividend policy: "At the moment, the investment community seems to be more desirous of receiving returns in the form of dividends rather than trying for capital appreciation" (3/16/1975). For our purpose, the most illuminating references make an explicit connection to dividend policy. The theory that dividend supply responds to tax clienteles is suggested in the following: "The Senate Finance Committee bill ... would reduce the effective tax rate on dividends [from 50 to 27 percent], while raising the rate on capital gains [from 20 to 27 percent]. ... Pressure will rise on corporations to increase dividend payouts ..." (6/1/1986). A column inspired by the working paper version of Fama and French (2001) cites stock options: "One explanation [for the decline in percent of payers in the S\&P] is ... stock options ... arguably providing an incentive to companies not to pay dividends" (1/4/2000). The same article also makes reference to catering to sentiment for dividends: "The most likely explanation [for decline in percent of payers in S\&P] ... would seem to be the most obvious. Investors, after seeing year after year of huge capital gains, no longer see much of a need for dividends as an assured return if the market declines ..." (1/4/2000).

Not surprisingly, some references are not specific enough to be unambiguously grouped into a single theory. References to taxes are particularly difficult, because they could relate to mechanisms in our clientele equilibrium hypothesis, our catering hypothesis, and our slow learners hypothesis. For purposes of Table A and Table 2, our default is to group tax references into clientele equilibrium unless there is reason to do otherwise. This should be kept in mind when reviewing the tables.

\section{Lessons from news analysis}


For the patient reader, a read through Table A offers a fascinating account of the (noncharacteristics) influences on dividends that were viewed as important by the financial press. It provides rich historical context for the quantitative analysis in the next section. As summarized in Table 2, it offers several initial lessons.

One lesson is that references to agency and asymmetric information are rare. Indeed it is difficult to find even oblique references to these hypotheses. Of course, there would have been many allusions to inside information or self-dealing if we had not required the abstract to contain the word "dividend" at least twice. Any reference to hostile takeovers, expropriation by insiders, or non-value-maximizing investment policy, for example, could be viewed as a reference to agency, and would have been classified as such in our analysis. Our results do not indicate that such forces are not recognized in the financial press; just that they do not appear in articles selected to contain a discussion of dividends. In general, this fits with the CFO survey results of Graham and Harvey (2001). They find that CFOs rarely attribute their financial policy decisions to concerns about free cash flow or asymmetric information. ${ }^{8}$

References to transaction costs, institutional investment constraints, and executive stock options are also rare. We are unable to find any reference even to the general notion that investors finance consumption with stock sales when dividends are insufficient, let alone a discussion of how transaction costs affect homemade dividends strategies or the demand for dividends. The timing of the references to institutional constraints and stock options, if not their number, is noteworthy. One reference alludes to the 1974 ERISA limitations on pension fund

\footnotetext{
${ }^{8}$ As Graham and Harvey note, it is possible that such influences are impounded into prices or credit ratings and managers react to them indirectly. In our context, however, this argument would boil down to the assertion that the underlying causes of sharp changes in the propensity to pay dividends, changes that affected hundreds or thousands of the economy's largest firms, had completely escaped the attention of the New York Times for over three decades.
} 
investments. Two references connecting stock options to dividend policy have appeared since 1999, but none before that.

Tax and catering references are the most frequent. Tax references are scattered throughout the sample. Those that appear around the crucial 1977 turning point include a proposal to eliminate double taxation of dividends, and a proposal to withhold taxes on dividend income. Tax integration would have reduced the tax disadvantage of dividends, while withholding would have increased it for tax cheats. Both proposals were defeated within a few years, however, and thus could not explain the continuing downward trend in dividend payment. The timing of the big clusters of catering references, on the other hand, are roughly consistent with patterns in the propensity to pay. The bulk of the references to positive sentiment for dividends appear in the years leading up to 1977 , as the propensity to pay was rising to its peak. Most of the negative sentiment references occur in the last few years of the sample, when the propensity to pay was low and falling.

A final lesson from Table 2 is that our list of candidate explanations appears to be sufficiently comprehensive, in the sense that we do not see references to any pervasive force that would suggest a specific addition to this list. There are isolated episodes such as Nixon's encouragement to limit dividend growth to four percent per year in the early 1970's - but Figure 1 shows that the propensity to pay had been declining for several years prior. The Nixon controls could be an influence in this specific era, but do not represent a pervasive force. Similarly, there are several references in the mid-1970's to the notion of dividends as a "hedge against inflation," a notion dissected by Modigliani and Cohn (1979). These references seem most appropriately viewed in connection with the sentiment references that appear at the same time, however, and again not as a distinct and pervasive force. 
This analysis gives us some initial clues about the relative plausibility of our candidate explanations. The tally in Table 2 tells us which forces were noticed by the financial press, and thus (arguably) more salient to those who set dividend policy, and which forces must have been working in the background if at all. It also tells us that catering and tax-based explanations are among the stronger contenders for explaining multiple trends in the propensity to pay, as opposed to isolated segments, since they are cited throughout the sample period. Of course, this entire analysis, while quite useful for several purposes, comes with substantial caveats. For example, one expects a bias toward reporting the sensational, such as colorful political fights over tax policy. In the next section, we complement the impressions from the Times with a more formal statistical analysis.

\section{Time series analysis of the propensity to pay}

By definition, the propensity to pay must be driven by some time series influence. In our second analysis we attempt to explicitly connect the propensity to pay to a set of empirical proxies for non-characteristics influences on dividends. The basic idea is to see whether these proxies line up, visually or in regressions, with the trends in Figure 1. As explained below, the regressions also reveal the extent to which we can "solve" the disappearing dividends puzzle as it is posed by Fama and French (2001).

\section{A. Proxy variables}

Good proxies do not exist for all of our candidate explanations. In particular, we are not aware of plausible time-series measures of agency costs, investment constraint-driven dividend clienteles, or the degree of "learning" about tax effects of dividends. Table 3 shows the data that we have been able to assemble, which includes proxies for asymmetric information, tax 
clienteles, transaction cost clienteles, catering incentives, and executive stock options. For reference, the table also lists the two propensity to pay series. We briefly describe each of these measures below. More details are in Appendix 1.

Asymmetric information is inherently difficult to measure. Our approach is to proxy for it using the average bid-ask spread reported by Jones (2002). To the extent that other components of the spread, such as inventory and order-processing costs, are roughly stable over time, models such as Copeland and Galai (1983), Glosten and Milgrom (1985), and Easley and O'Hara (1987) suggest that the observed spread is increasing in the asymmetry of information across market participants. Consistent with this interpretation, Barclay and Smith (1988) find that spreads tend to widen around open-market repurchase announcements.

Our proxies for the prevalence of tax-based clienteles are measures of the net tax advantage of dividends for individuals and for corporations. The variable we focus on is the ratio of the after-tax value of a dollar in dividends to the after-tax value of a dollar in long-term capital gains. Poterba (1987) and Bernheim and Wantz (1995) consider similar measures. As described in Appendix 1, the individual tax rates are weighted averages across groups of shareholders at different marginal rates.

We proxy for the size of transaction cost-based clienteles using two proxies for the cost of making homemade dividends. The first is based on data in Jones (2002). He reports average fixed trading commissions on Dow Jones stocks and average bid-ask spreads for NYSE stocks. For us, the relevant measure is the total one-way cost, estimated as one-half the bid-ask spread plus the average commission on NYSE stocks. As a second measure, we consider the share of total stock market capitalization held through mutual funds. Fama and French (2001, p. 40) suggest that the cost of creating homemade dividends through transactions in a mutual fund 
account could be lower than the cost of buying and selling shares directly. If so, then the mutual fund share should be inversely related to effective transaction costs.

Our measure of catering incentives is from Baker and Wurgler (2002). They construct a stock market "dividend premium" variable as the difference between the average market-to-book ratios of dividend payers and nonpayers (where the average is either equal- or book valueweighted). They argue that when the dividend premium is positive, there exists a general stock market incentive to pay dividends, and an incentive not to pay when it is negative. Note that this measure of investor demand for dividend payers would reflect both rational clientele demands as well any investor sentiment for payers.

The last concept we were able to find some reasonable proxies for is executive option compensation. From the Hall and Liebman (1998) study of CEO compensation in several hundred large companies, we take the mean value of options grants as a share of the mean total of options grants, salary, and bonus. Conference Board surveys of top executive compensation provide a second measure, longer but noisier than the Hall and Liebman variable. It is the percentage of the large public corporations in the survey that report having an executive option plan (of any size) in place.

\section{B. Plots}

Recall that we need to explain four distinct trends in the propensity to pay that appear in Figure 1: (i) an increase from 1963 through 1966-68, depending on how one measures PTP; (ii) a decrease from 1967-69 through 1972-74; (iii) an increase from 1973-75 through 1977; and (iv) a decrease from 1978 through 2000. We can get an initial assessment of which of these proxy variables could be relevant to these trends just by plotting them. Figure 2 shows these plots. 
Looking first at the 1963 through 1966-68 period, the figure suggests that the dividend premium is the only variable that would have predicted the consistent increase in the propensity to pay. The dividend premium is positive through 1966, possibly representing a catering incentive for dividend payment. The tax clientele proxies are moving in the right direction over this period, with taxes becoming increasingly favorable to dividends, but the magnitude of these changes seems too small to explain a robust supply response. The options plans variable increases through 1969 , thus predicting a decline in the propensity to pay rather than an increase. The other proxies display no significant trends.

None of the variables clearly explains the second trend, the declining propensity to pay through the early 1970's. The tax advantage continues to increase over these years, the wrong direction to explain a decline in dividends. The dividend premium does go substantially negative for a few years, consistent with the declining propensity to pay, but it rebounds a bit too early for a clear catering interpretation. The equal-weighted version of this variable, in Table 3 but not plotted, does somewhat better; it falls lower than the value-weighted version, and remains low for another year. The option plans variable shows an equally consistent pattern: It increases through about 1970, consistent with the declining propensity to pay, but then it falls off. However, note that Nixon was offering moral suasions against dividends from precisely late 1971 through early 1974. Given the Times articles about the effect of this policy, an appealing explanation is that Nixon kept the propensity to pay in decline in the early 1970's even though catering and options measures began to point the other way.

Regarding the third trend, the sharply increasing propensity to pay in the mid-1970's, the plots are consistent with a role for catering and stock options. The positive dividend premium that appears in this period is consistent with the Times references to positive sentiment for 
dividends discussed earlier. The percentage of firms that report having executive options plans also falls by several points over this period, contrary to conventional wisdom that the use of stock options has grown monotonically for the past few decades, possibly increasing the willingness to pay dividends.

The plots uncover several forces consistent with the fourth trend, the striking decline in the propensity to pay that begins in 1978. A decline in the cost of making homemade dividends is suggested in the Jones (2002) one-way costs variable, the growth of mutual funds, and the emergence of dividend reinvestment plans. The bid-ask spread also displays a general decline since the late 1970's, perhaps indicating a reduced need to signal with dividends. Both stock options proxies show a significant increase in the use of options, again consistent with a reduced propensity to pay. On the other hand, proxies for tax clienteles clearly do not line up with this trend. The tax preference for dividends has, if anything, increased significantly since the mid1970's.

While our transaction costs, options, and asymmetric information proxies have been moving in a direction that is generally consistent with the most recent disappearance of dividends, only the dividend premium variable seems to address why the downturn started in 1978, as opposed to several years earlier or later. It turns negative in 1978 and remains there through 2000 (except for a blip in 1998), thus predicting a sustained disappearance under the logic of the catering theory. The wide discount in 1999 in the value-weighted version, and the deeper and more consistent discount in the equal-weighted version, seems consistent with the Times references to negative sentiment for dividends in these years. 


\section{Regressions to explain the propensity to pay}

We turn to regressions to more formally estimate the determinants of the propensity to pay. As a preliminary step, we need to settle on the theoretically appropriate specifications. The majority of our candidate explanations propose an equilibrium relationship between the propensity to pay and a non-characteristics influence on dividends. For example, the clientele equilibrium view holds that the level of the propensity to pay is closely connected to the relative size of dividend and non-dividend clienteles. The asymmetric information theory also emphasizes equilibrium. The nature of the relationship between dividend payment and executive options is less clear, but it has an equilibrium flavor. Thus, for these theories, the natural specification is simply

$$
P T P_{t}=a+b X_{t}+u_{t},
$$

where $P T P$ is the propensity to pay and $X$ is a proxy for clienteles, asymmetric information, or stock options.

Time series regressions of this form have an econometric problem. As shown by Granger and Newbold (1974), they give misleading inferences when the variables are not stationary. ${ }^{9}$ To examine whether this is a concern in our data, Table 4 reports the results of Dickey-Fuller tests for unit roots, as well as autocorrelations and cross-correlations. The unit root tests confirm the potential for spurious regressions: they fail to reject a unit root in any of the variables. However, after differencing, a unit root is always rejected. This suggests that in cases for which the model in Eq. (1) is theoretically appropriate, we should also estimate the parallel form

\footnotetext{
${ }^{9}$ There are theoretical reasons to expect several of our variables to be stationary in the large-sample sense. For instance, the mutual fund share, the options proxies, the propensity to pay, and changes in the propensity to pay are bounded by construction. (We obtain similar regression results if we apply a logistic transformation to the actual and expected rates of payment.) Economic considerations suggest that the tax advantage variables and the dividend premium also cannot grow without bound.
} 


$$
\Delta P T P_{t}=a+b \Delta X_{t}+v_{t},
$$

where the deltas denote differences, and perhaps give more weight to these inferences.

The catering theory involves dynamics in disequilibrium, and thus suggests a different regression specification. The theory proposes that uninformed investor demand for dividend payers fluctuates faster than firms can adjust. A nontrivial dividend premium (or discount) appears, and firms cater to the implied excess demand. The appropriate specification for evaluating this dynamic is to regress changes in the propensity to pay on the beginning-of-period level of the dividend premium

$$
\Delta P T P_{t}=a+b X_{t-1}+w_{t},
$$

where $X$ is the dividend premium. Fortunately, we can nearly reject a unit root in the level of the dividend premium, with p-values at 0.10 for the equal-weighted series and 0.16 for the valueweighted series (Table 4), and there are also strong prior theoretical reasons to believe that it is stationary. As a result, we do not make further adjustments to this specification.

Table 5 reports the regression results. The levels-on-levels regressions and the differences-on-differences regressions generally do not find strong support for any of our equilibrium-based theories. The tax variables consistently take the wrong sign. The transaction cost proxies flip sign between the full sample and the early subsample. Options variables, by contrast, do slightly better. The levels specification for the options share of CEO compensation works through a common trend, as the relationship disappears in differences. On the other hand, the options specifications are not as tightly motivated by theory as the clientele equilibrium specifications, for instance, and we are working with only 15 observations on the options share variable, so these mitigating factors should be kept in mind. 
Turning to the changes on levels specifications, the most noteworthy result is the comparatively robust effect of the dividend premium. It has the sign hypothesized by the catering theory, and keeps the same magnitude across sample periods and whether or not the market-tobook ratio is included in the logits used to estimate the propensity to pay. This might have been anticipated from the earlier plots.

We also report changes-on-lagged-levels specifications for the clientele demand proxies, because in principle they could shed light on the source of investor demand behind the dividend premium effect. If firms are catering to clientele demand, for example, then we might also hope to find that one or more of the clientele proxies themselves affect changes in the propensity to pay when the dividend premium is excluded (in the logic of the theory, the dividend premium is a summary statistic for excess clientele demand). If firms are catering to sentiment for dividends, on the other hand, then there is no particular reason to expect that clientele proxies would enter in these specifications. However, Table 5 shows that none of our clientele proxies has a robust effect in these specifications. Without evidence for any particular clientele behind the dividend premium, process of elimination suggests a role for investor sentiment.

To summarize, our regression analysis tends to reinforce support for one of the candidate explanations that also performed well in the news analysis, catering to time-varying sentiment for dividend payers, and casts serious doubt on another, tax clientele equilibrium. The options explanation receives an intermediate degree of support. Agency, slow learning, and investment constraints-based explanations get an incomplete; we lack the data to evaluate them.

\section{Out-of-sample forecast}

Fama and French (2001) emphasize the most recent decline in the propensity to pay. Given the prominence of this result, an important question is whether any of our proxies could 
"explain" it as an empirical matter. To give a precise answer to this question, one needs to stay faithful to their empirical framework. To review, they use the 1963-1977 Compustat data to fit a model of the expected percentage of payers, and then they evaluate this model at the sample characteristics that prevail from 1978 and forward to make a true out-of-sample forecast of the expected percentage in each year. The difference between the actual and the expected percentage is the propensity to pay, which by 2000 has reached -30 percent. The details of their procedure are given in Appendix 1.

This procedure suggests a natural way to determine whether a given time-series variable is capable of accounting for this decline. Start by taking the propensity to pay variable as data. Then fit a regression model between the propensity to pay and the candidate variable over the 1963-1977 series, and use the fitted model to forecast the expected propensity to pay from 1978 forward. If the actual decline in the propensity to pay lines up with this forecast, then as an empirical matter the disappearance of dividends, as it is posed by Fama and French (2001), has been "explained."

Intuitively, to be successful in this exercise, a candidate variable must have a stable relationship with the propensity to pay. If it does not, then the out-of-sample forecast error will blow up. The other key requirement is a good fit. If the model has little explanatory power then its forecasts will be inaccurate, even if they are not systematically biased. These considerations suggest that we consider the option plans and the dividend premium variables as candidates in this exercise, since in Table 5 they are the variables that obtain roughly similar coefficients (of the right sign) in both the 1963-1977 subperiod and the full sample, and high t-statistics at least in some specifications. (In univariate regressions estimated in the same sample and with the same dependent variable, ranking t-statistics is the same as ranking the $R^{2}$.) 
Table 6 shows the out-of-sample forecasts using the option plans variable. It appears incapable of explaining the magnitude of the post-1978 decline - its forecast for the expected propensity to pay is too little, too late. The pathology of this failure can be understood by looking at the forecasting model itself, and the basic pattern of option plans variable. That is, comparing the early sample and full sample coefficients in Panel B, one can see that the coefficient in the in-sample model is smaller than it wants to be to explain PTP out of sample. In addition, the option plans variable doesn't begin its increase until 1994. By then, virtually all of the "disappearance" has already occurred. ${ }^{10}$

In contrast, Table 7 shows that the dividend premium variable is better able to account for the magnitude of the disappearance. ${ }^{11}$ The forecast error when market-to-book is included is always less than 10 percentage points (and usually positive), and less than 6 percentage points (and usually negative) when it is excluded. Given that the propensity to pay is itself surely measured with at least a few percentage points of error, this is probably about as good as one could hope to achieve.

\section{Other time-series patterns involving dividend policy}

Our main goal is to determine the cause of fluctuations in the propensity to pay dividends. However, another angle from which to evaluate our candidate explanations for those trends is to examine the extent to which the same explanations are consistent with related trends in the data. Of particular interest are other time-series patterns that, like the propensity to pay

\footnotetext{
${ }^{10}$ The Hall and Liebman sample is not long enough to use in this exercise. However, they report that the median options grant is $\$ 0$ until 1985. Again, by this year half of the disappearance has already taken place.

${ }^{11}$ Since the dividend premium-based forecasts are generated from the changes on levels regressions in Table 5, we forecast changes in the propensity to pay, starting in 1978, and then cumulate them to estimate the expected propensity to pay from year to year.
} 
dividends, cannot be clearly attributed to firm characteristics, and hence are more likely to be "out of sample" reflections of the same underlying economic forces.

We are aware of two such patterns, both suggested by recent research ${ }^{12}$ The first is that the propensity to repurchase shares has increased in recent years. The second is that changes in the propensity to pay dividends help to predict the relative stock returns of payers and nonpayers. It is beyond the scope of this paper to conduct thorough analyses of these two facts, both of which are very interesting in their own right. Here we limit ourselves to a brief discussion of the extent to which they are, in principle, consistent or inconsistent with our candidate explanations for fluctuations in the propensity to pay dividends.

\section{A. Dividends disappearing, repurchases appearing}

Share repurchases increased dramatically in the mid-1980's, a trend identified by Bagwell and Shoven (1989). Grullon and Michaely (2002) document growth in repurchases whether measured as a raw level, as a share of total payouts, or as a percentage of firms that use them. Their results come close to establishing that the propensity to repurchase, in the Fama and French (2001) sense of controlling for characteristics, has been increasing in recent decades, even as the propensity to pay dividends has been decreasing. ${ }^{13}$ This points to a clear screen for our candidate explanations: They must distinguish between dividends and repurchases in order to explain a secular trend away from one and toward the other.

\footnotetext{
${ }^{12}$ DeAngelo, DeAngelo, and Skinner (2002) document a number of interesting trends in dividend payment. We do not cover them here because, as the authors show, they reflect changes in firm characteristics. For instance, DeAngelo et al. document that continuing payers have increased dividends in concert with their earnings. They also show that the majority of the disappearance of small-dividend payers comes about via acquisition or financial distress, circumstances likely to be closely connected to characteristics. Although we do not consider their results in detail, it is worth noting that DeAngelo et al. conclude that their results do not support asymmetric information or clientele equilibrium theories. From a different set of empirical patterns, we reach the same conclusion.

${ }^{13}$ Fama and French observe that an increasing propensity to repurchase cannot completely account for the declining propensity to pay dividends, since repurchases are concentrated among current dividend payers.
} 
Most of our candidate explanations survive this screen. The most obvious survivors are those based on some tax mechanism, since taxes immediately draw a sharp distinction between dividends and repurchases. These include slow learning about taxes, tax-based asymmetric information models, and tax-clientele versions of clientele equilibrium and catering. Dividends are also distinct from repurchases under the stock options hypothesis and a catering-to-sentiment hypothesis. The comparative stability of dividends makes them better for financing consumption, so theories involving transaction-cost clienteles also seem capable of a distinction. Finally, certain investment constraints, such as spending from income but not capital, or dividend payment as a proxy characteristic of a prudent investment, make dividends and repurchases imperfect substitutes for some investors.

This screen does turn out to have some bite, however. One prominent theory that inherently fails to separate dividends and repurchases is the investment-based asymmetric information model, such as Miller and Rock (1985). The problem is that dividends and repurchases enter the sources-uses constraint in the same way. In addition, the agency view of payouts also does not inherently distinguish between dividends and repurchases. According to Easterbrook (1984, p. 655), they are equally good at tying managers to the discipline of the capital markets. According to Jensen (1986), they are equally dominated by debt.

\section{B. $\quad$ Changes in propensity to pay predicts stock returns}

Baker and Wurgler (2002) find that the aggregate rate of dividend initiation and omission are strong predictors of the relative stock returns of payers and nonpayers. When initiations are common, returns on payers are relatively low over the next one to three years. When omissions are common, the opposite holds. Since changes in the percentage of dividend payers depend mechanically on initiations and omissions, these results immediately suggest that changes in the 
propensity to pay may also predict relative returns. ${ }^{14}$ This is worth checking because any novel relationship that directly involves the propensity to pay could give useful leverage to discriminate among alternative explanations.

Table 8 generally confirms the expected pattern. In the top panel, the dependent variable is the difference between the returns on value-weighted indexes of payers and nonpayers, and the independent variable is the (standardized) change in the propensity to pay. The other panels regress payer and nonpayer returns separately to see whether the relative return predictability can be attributed solely to one of these components. The table reports ordinary least-squares coefficients and coefficients adjusted for the small-sample bias analyzed by Stambaugh (1999). The p-values in the table represent a two-tailed test of the hypothesis of no predictability using the bootstrap described in Baker and Wurgler (2002). OLS p-values would indicate uniformly higher levels of significance (unreported).

The results in Table 8 echo the predictability associated with initiation and omission in Baker and Wurgler (2002), though they are not quite as strong as the results there. One clear pattern is the difference between the results that include and exclude the market-to-book ratio from the PTP measure: Those that include it are at best marginally significant, while those that exclude it are very strong. Figure 1 provides a compelling explanation for this difference. Panels $\mathrm{C}$ and $\mathrm{D}$ of that figure indicate that the inclusion of market-to-book essentially just adds highfrequency noise to the four low-frequency trends in PTP. The fact that evidence of predictability gets stronger when measurement error is reduced tends to bolster our confidence that the predictability pattern is genuine.

\footnotetext{
${ }^{14}$ The mechanical connection is not exact, because the change in the percentage of payers is also affected by new lists and delists. Further, characteristics are taken out when defining the propensity to pay.
} 
The pattern of predictability seems most consistent with catering. The catering theory proposes that firms tend to pay dividends when dividend payers are relatively highly priced. This logic predicts that increases in the propensity to pay will, as arbitrage slowly corrects the relative mispricing, forecast decreases in the relative return on payers. The results in Panel A would be consistent with this dynamic working at horizons of roughly a few years. It is hard to articulate how other candidate explanations would imply this predictive relationship (or the closely related results involving initiations and omissions).

\section{Summary}

In this paper, we evaluate explanations for the major time trends in the propensity to pay dividends documented by Fama and French (2001). We employ three very different types of analysis in an effort to be as comprehensive as practically possible: a review of historical New York Times articles that involve dividends; a formal analysis of time series relationships between the propensity to pay and proxy variables for driving influences; and a discussion of the capacity of our candidate explanations to incorporate related patterns in the data.

\section{A. A scorecard}

Table 9 summarizes our findings into a rough scorecard. The first column indicates which candidate explanations receive a nontrivial number of references (more than two) within our 32year sample of New York Times articles that involve dividends. Media attention centers on three explanations: clientele equilibrium theories emphasizing taxes, catering (usually to investor sentiment, not to rational dividend clienteles), and slow learning about taxes.

The next columns report the ability of our candidate explanations, as embodied by time series proxy variables, to explain the four distinct trends in the propensity to pay dividends that 
occur between 1963 and 2000. Not surprisingly, we found that it is usually possible to line up a given proxy variable with at least one trend. The dividend premium variable, our proxy for catering incentives, lines up with all four, strong evidence that it is capturing a pervasive and genuine effect. It tends to be positive when the propensity to pay is increasing, and negative when it is decreasing, consistent with catering. Unfortunately, our proxies do not cover all of the candidate explanations, so some entries are left blank. The slow learning about taxes view is an exception. Since this theory predicts a gradual decline in the propensity to pay, we know that even without a proxy for "learning," this view could not explain the upturns in the propensity to pay in the mid-1960's and mid-1970's.

The sixth column reports the ability of our proxy variables to "explain" the post-1978 disappearance in the specific empirical sense of Fama and French (2001). The dividend premium variable can account for the magnitude of the decline in the out-of-sample forecasting exercise that their methodology suggests. Our other proxies are less successful, because they do not bear a sufficiently strong and robust relationship to the propensity to pay.

The last columns show which of our candidates are, in theory, consistent with two additional time-series patterns that involve dividends and that cannot be directly attributed to firm characteristics. The table indicates that several explanations are compatible with the fact that the propensity to repurchase has increased even as the propensity to pay dividends has declined. In contrast, only catering appears to offer a natural explanation for why changes in the propensity to pay would be inversely related to the future excess stock returns of payers over nonpayers.

Table 9 also illustrates the strength and the weakness of our approach. The strength is the breadth of the analysis, in terms of the number of hypotheses and the range of phenomena that 
we attempt to address. The payoff to this is clear from a look down the fifth column, "Down 1978-2000." Had we limited our scope to just this single trend, the one emphasized by Fama and French, we would have had little power to reject any hypotheses. It is always possible to match up a single time trend with another time trend. More progress is possible if one applies a consistent theoretical perspective to all aspects of the data, and considers the evidence as a whole. This approach leads to a clear conclusion: If one is looking for a single explanation for fluctuations in the propensity to pay dividends between 1963 and 2000, catering is the best candidate.

The weakness of our approach is that data do not exist to evaluate all hypotheses on all dimensions. Invariably we are forced to leave some blank cells in the scorecard. However, as it stands, the scorecard suggests that more data is unlikely to change the basic conclusion: None of the explanations for which we lack a very good proxy variable - agency, stock options, investment constraints-based clientele theories, and learning about taxes - receive robust support from the analyses that are available. As the table indicates, even if one gave these theories the full benefit of the doubt and replaced each blank in the table with an "X," each of them would still fail to address multiple aspects of the data.

\section{B. A stylized account of the propensity to pay dividends, 1963-2000}

We conclude the paper by offering a stylized account of the propensity to pay dividends between 1963 and 2000. This would not be necessary if the propensity to pay was related to a variable with a simple interpretation, like taxes. As it stands, the propensity to pay depends on the dividend premium, so it is incumbent on us to attempt at least a preliminary description of the evolution of this apparently crucial variable. And given that we were unable to attribute the dividend premium's effect to any of several proxies for dividend clienteles, as well as the 
frequent references to catering to sentiment (as opposed to clienteles) in the Times, our task boils down to describing the evolution of sentiment for dividends. This is still not a simple task. To our knowledge, the only semi-rigorous way to construct a timeline of sentiment is to identify common themes from academic histories of the capital market and discussions in the media. We take this approach below. We also attempt to integrate into the narrative certain other influences that the evidence suggests may have played some role.

We begin in 1963. The very high dividend premium in this year seems to be fallout from the 1962 crash in small growth stocks. As Malkiel (1990, p. 54 - 57) describes it, "The new-issue mania rivaled the South Sea Bubble in its intensity and also, regrettably, in the fraudulent practices that were revealed. ... The tronics boom came back to earth in 1962.... Growth stocks ... took the brunt of the decline, falling much further than the general market. Yesterday's hot issue became today's cold turkey." By 1963, the relatively greater fall of small growth stocks, typically nonpayers, was manifest in a high dividend premium. ${ }^{15}$ In a pattern that repeats in later years, investors appear to have reacted to the crash by turning toward the "safer" returns on income-producing stocks, and firms catered by increasing their propensity to pay.

According to Malkiel and the Times, the late 1960's saw the return of a speculative market and with it a shift in demand toward nonpayers. The Times writes, "During the speculative market of the late 1960's many brokers told customers that it didn't matter whether a company paid a dividend - just so long as its stock kept going up" (9/13/1976). ${ }^{16}$ The bull

\footnotetext{
${ }^{15}$ Consistent with this dynamic, Fuller and Goldstein (2002) find that payers have higher (less negative) returns than nonpayers in months in which the S\&P Index return is negative. This pattern also holds after controlling for various factor loadings.

${ }^{16}$ An interesting note is that bond returns are also poor in this period. Homer and Sylla (1996, p. 380) argue that "people began to think that the bond market was a thing of the past." One possibility is that since dividend payers and bonds both share a highly salient "income" characteristic, investors were withdrawing from both categories in favor of securities that offered full potential for capital gains. A clearer link between bonds and dividend payers occurs in the late-1970's, as described below.
} 
market ended in 1970, and the dividend premium was again positive by 1971. But at this point, Nixon had begun his exhortations against increasing dividends, which Times accounts suggest were having some effect (see also Baker and Wurgler (2002)). This odd intervention seems likely to explain why the propensity to pay kept declining for a few more years, even though the positive dividend premium indicated the return of a demand for payers.

The mid-1970's witnessed a high dividend premium and an increasing propensity to pay dividends. According to the New York Times, the 1973 and 1974 bear market appears to have engendered another return to the perceived safety of dividend payers and sustained an already high dividend premium: "Thanks to ... [characteristics and] the rising yield-consciousness of stockholders, corporations are fattening their dividend payouts. ... As investors became chary of the stock market, they were less apt to count on future earnings growth ... and more likely to return to the bird-in-the-hand rationale of cash dividends." (11/7/1976). Thus part of the increase in the propensity to pay seems to reflect catering, and another part may be due to the lifting of Nixon's controls.

The most interesting episode is the late 1970's. As noted earlier, the dividend premium drops sharply, is negative by 1978 , and deeply negative by 1979 . And the propensity to pay dividends begins its long decline. What happened? Historical accounts suggest that the distaste for dividend payers was closely connected to an emerging distaste for the other prominent income-producing security, bonds, which had been punished for several years by high inflation. Homer and Sylla (1996, p. 381-386) describe the fiscal circumstances contributing to high yields, and Malkiel (1990) details the declining sentiment for bonds. ${ }^{17}$ Investors appear to have simultaneously withdrawn from two major categories, bonds and dividend-paying stocks. Thus

\footnotetext{
${ }^{17}$ Malkiel relates a joke which appeared in 1981: "'A bond is a fixed-rate instrument designed to fall in price."”
} 
references to positive sentiment for dividends, frequent in the Times in the years leading up to 1978, suddenly disappear, as do references to a preference for "income" or "yield" or to the belief that dividends provide a hedge against inflation. Modigliani and Cohn (1979) capture the shift in sentiment: "Until their poor performance in recent years, equities had traditionally been regarded as an ideal hedge against inflation" (p. 24).

Our time series proxies suggest that other trends, such as declining transaction costs, may also have depressed the demand for payers through the 1980's and 1990's. Easier to defend influences are on the supply side, in particular the explosion in stock options and the 1982 introduction of Rule 10b-18, which Grullon and Michaely (2002) show to have paved the way for repurchases. However, our rather extensive search turns up no evidence that any of these factors initiated the post-1978 decline in the propensity to pay. Like previous sharp turning points in the propensity to pay, this switch appears to have been initiated by a switch in investor attitudes. Options, repurchases, and perhaps clienteles have propagated the decline, once already underway. $^{18}$

Sentiment for nonpayers returned with the Internet, reinforcing if not overwhelming the complementary trends in options, repurchases, and perhaps traditional clienteles. At the beginning of 2000 the equal-weighted dividend premium was at its sample minimum of -74.90 percent, and the value-weighted variable had also reached its sample minimum of -33.17 percent. This episode is recent enough to be familiar to most readers; Richardson and Ofek (2002) provide a detailed analysis. The Times summarizes the prevailing attitude: “Today's

\footnotetext{
${ }^{18}$ Of course, the dividend premium remains consistently negative from 1978 through 2000 , so it is not strictly necessary to appeal beyond catering incentives to explain the continued decline. Nevertheless, the results of Fenn and Liang (2001) and Grullon and Michaely indicate that options and repurchases have played at least a supporting role.
} 
investors, fixated on making a quick buck, are likely to wonder how anyone could ever have been interested in something so obviously irrelevant as dividends" (8/6/2000).

\section{Epilogue}

As of this writing in late 2002, Internet stocks have officially crashed and most market observers characterize the current situation as a bear market. After earlier crashes, investor preferences shifted toward dividends, and there is anecdotal evidence that this is happening once again. For example, the title of a 1/28/2002 article in the Times suggests that investors have been finding, or at least seeking, "Solace In Stocks That Pay Dividends." It will be interesting to see whether dividends reappear in the next few years. 


\section{Appendix 1. Compustat data and time series variables}

\section{A.1. Compustat sample}

The 1962-2000 Compustat sample is defined following Fama and French (2001, p. 4041): "The Compustat sample for calendar year $t \ldots$ includes those firms with fiscal year-ends in $t$ that have the following data (Compustat annual data items in parentheses): total assets (6), stock price (199) and shares outstanding (25) at the end of the fiscal year, income before extraordinary items (18), interest expense (15), [cash] dividends per share by ex date (26), preferred dividends (19), and (a) preferred stock liquidating value (10), (b) preferred stock redemption value (56), or

(c) preferred stock carrying value (130). Firms must also have (a) stockholder's equity (216), (b) liabilities (181), or (c) common equity (60) and preferred stock par value (130). Total assets must be available in years $t$ and $t-1$. The other items must be available in $t$... We exclude firms with book equity below $\$ 250,000$ or assets below $\$ 500,000$. To ensure that firms are publicly traded, the Compustat sample includes only firms with CRSP share codes of 10 or 11, and we use only the fiscal years a firm is in the CRSP database at its fiscal year-end. ... We exclude utilities (SIC codes 4900-4949) and financial firms (SIC codes 6000-6999)." The average number of firms in the sample between 1963 and 1977 (1978 and 2000) is 1,776 (3,797).

\section{A.2. Firm characteristics and dividend payment}

Firm size, investment opportunities, profitability characteristics, and dividend payment are defined following Fama and French (2001). NYP is the NYSE market capitalization percentile, i.e. the fraction of firms on the NYSE having equal or smaller capitalization than firm $i$ in year $t . M / B$ is the market-to-book ratio, defined as book assets minus book equity plus market equity all divided by book assets. Market equity is fiscal year closing price times shares outstanding (199 times 25). Book equity is stockholders' equity (Item 216) [or first available of 
common equity (60) plus preferred stock par value (130) or book assets (6) minus liabilities (181)] minus preferred stock liquidating value (10) [or first available of redemption value (56) or par value (130)] plus balance sheet deferred taxes and investment tax credit (35) if available and minus post retirement assets (330) if available. Growth in book assets $d A / A$ is self-explanatory. Profitability $E / A$ is earnings before extraordinary items (18) plus interest expense (15) plus income statement deferred taxes (50) divided by book assets. A firm-year observation is a dividend payer if it has positive dividends per share by the ex date, else it is a nonpayer.

\section{A.3. Propensity to pay dividends}

The propensity to pay dividends is estimated following Fama and French (2001). FamaMacBeth logit regressions of the probability that a firm with given characteristics is a dividend payer are estimated year by year, from 1963 to 1977, in the Compustat sample, and the coefficients are averaged across years. Two logit models are fit in this manner. One includes the characteristics $N Y P, M / B, d A / A$, and $E / A$, and the other excludes $M / B$ :

$$
\operatorname{Pr}\left(\text { Payer }_{i t}=1\right)=\operatorname{logit}\left(-0.14+4.26 N Y P_{i t}-0.81{\frac{M}{B_{i t}}}-1.07 \frac{d A}{A}_{i t}+15.57 \frac{E}{A_{i t}}\right)
$$

and

$$
\operatorname{Pr}\left(\text { Payer }_{i t}=1\right)=\operatorname{logit}\left(-0.63+3.60 N Y P_{i t}-1.39{\frac{d A}{A_{i t}}}_{i t}+10.34 \frac{E}{A_{i t}}\right)
$$


The expected percentage of dividend payers in the Compustat sample in year $\mathrm{t}$ is then estimated by applying Eqs. (A.1) and (A.2) to the values of the explanatory variables for each firm, summing over firms, dividing by the number of firms and multiplying by 100 . The propensity to pay dividends PTP in year $\mathrm{t}$ is defined as the difference between the actual and expected percentage of payers.

\section{A.4. One-way transaction costs and the bid-ask spread}

Jones (2002) reports an annual time series of the average percent commission on roundlot NYSE transactions and of the average percent bid-ask spread on Dow Jones Industrial Average stocks. Total one-way trading costs in a given year are measured as one-half the average bid-ask spread plus the average commission.

\section{A.5. Mutual funds}

The Federal Reserve Flow of Funds reports the aggregate net asset value of equity mutual funds (Table L.122, row 10). They obtain their data from the Investment Company Institute. This value is divided by the aggregate NYSE/Amex/Nasdaq market capitalization from CRSP to measure the share of public equities held through mutual funds.

\section{A.6. Tax advantage of dividends}

The personal tax advantage for dividends (typically a net disadvantage) is measured as the relative after-tax income from dividends versus long-term capital gains for individual investors as calculated by the NBER TAXSIM model. The model computes average marginal income and long-term capital gains rates as the weighted average rates across shareholder groups (reported at www.nber.org/ taxsim/mrates/mrates2.html). See Feenberg and Coutts (1993) for a description of the TAXSIM model. Specifically, the personal tax advantage is one minus the average marginal income rate, divided by one minus the average marginal long-term capital 
gains rate, all minus one, and all multiplied by 100 . The corporate tax advantage of dividends is measured as the relative after-tax income from dividends versus long-term capital gains for $\mathrm{C}$ corporations. That is, we take one minus the product of the top $\mathrm{C}$ corporation income rate and one minus the intercorporate dividend exclusion, divided by one minus the capital gains rate, all minus one, all multiplied by 100. 1970-2000 corporate rates are from Graham (2001), earlier are from various issues of the IRS Statistics of Income: Corporation Income Tax Returns.

\section{A.7. Dividend premium}

The dividend premium variables are from Baker and Wurgler (2002). They compute the average (equal and book-value weighted) market-to-book ratio for dividend payers, and the average (equal and book-value weighted) for non-payers, for each year. The dividend premium is then the difference between the logs of these averages. They measure the market-to-book ratio using the calendar-year end stock price, rather than the fiscal-year end price, but otherwise follow the market-to-book definition given above.

\section{A.8. Executive stock options}

Large company executive stock option grants are from Hall and Leibman's (1997) extension of the sample in Yermack (1995). For each year between 1980 and 1994, Hall and Liebman report the mean value of CEO stock option grants and the mean value of CEO salary and bonus for the 400 or so largest publicly traded firms (where size is defined by Forbes). The prevalence of executive stock option plans is the percentage of firms reporting having some plan in the Conference Board's Top Executive Compensation surveys. The survey typically includes about 1,000 large public corporations, and spans all industries. We compute the weighted average prevalence of stock option plans in nonfinancial and nonutility industries to better match the industry composition of our Compustat sample. 


\section{Appendix 2. New York Times references to non-characteristics influences on dividends}

The sample of media references is gathered as follows. The database search engine Factiva is used to identify all New York Times articles published between January 1, 1969 (the first year of coverage in Factiva) and December 31, 2001 that contain "dividend" or "dividends" at least twice in the abstract. This leads to an initial sample of 1,567 unique articles to inspect more closely. The abstract of each article is read in order to categorize the article as a mistaken reference (e.g., using the word "dividend" metaphorically such as "peace dividend"), a simple straight news report of a dividend action, or as a potentially useful article. Specifically, 6 are mistakes, 374 report an impending dividend decision, 133 report an omission, 126 report a reduction, 393 report an increase, 51 report an initiation, and 145 report a dividend action but do not distinguish its nature.

The remaining abstracts suggest that the article contains some analysis of a specific dividend decision or a broader influence on dividends. 236 of these do not go beyond firm or broad economic characteristics (which are implicitly captured by firm characteristics), and so are irrelevant to the propensity to pay. The final sample of 103 abstracts includes all those that suggest that the article may reference a non-characteristics influence on dividends. Hard copies of these articles are gathered and read in full text. Table A lists the 95 references made in these 103 articles (some articles contain more than one relevant reference, while others turn out to contain none, despite what is suggested by their abstract). 


\section{References}

Allen, Franklin, Antonio E. Bernardo, and Ivo Welch, 2000, A theory of dividends based on tax clienteles, Journal of Finance 55, 2499-2536.

Allen, Franklin, and Roni Michaely, 2002, Payout policy, University of Pennsylvania working paper.

Amihud, Yakov, and Kefei Li, 2002, The declining information content of dividends and the effect of institutional holdings, New York University working paper.

Bagwell, Laurie Simon, and John B. Shoven, 1989, Cash distributions to shareholders, Journal of Economic Perspectives 3, 129-140.

Baker, Malcolm, and Jeffrey Wurgler, 2002, A catering theory of dividends, Harvard University working paper.

Barberis, Nicholas, and Andrei Shleifer, 2002, Style investing, Journal of Financial Economics, forthcoming.

Barclay, Michael J., and Clifford W. Smith, Jr., 1988, Corporate payout policy: Cash dividends versus open-market repurchases, Journal of Financial Economics 22, 61-82.

Bernheim, B. Douglas, and Adam Wantz, 1995, A tax-based test of the dividend signaling hypothesis, American Economic Review 85, 532-551.

Black, Fischer, 1976, The dividend puzzle, Journal of Portfolio Management, 5-8.

Black, Fischer, and Myron S. Scholes, 1974, The effects of dividend yield and dividend policy on common stock prices and returns, Journal of Financial Economics 1, 1-22.

Brav, Alon, and J. B. Heaton, 1998, Did ERISA's prudent man rule change the pricing of dividend omitting firms?, Duke University working paper.

Copeland, Thomas and Dan Galai, 1983, Information effects on the bid-ask spread, Journal of Finance 38, 1457-1469.

DeAngelo, Harry, Linda DeAngelo, and Douglas J. Skinner, 2002, Are dividends disappearing? Dividend concentration and the consolidation of earnings, University of Southern California working paper.

Del Guercio, Diane, 1996, The distorting effect of the prudent-man laws on institutional equity investments, Journal of Financial Economics 40, 31-62.

Dhaliwal, Dan S., Merle Erickson, and Robert Trezevant, 1999, A test of the theory of tax clienteles for dividend policies, National Tax Journal 52, 179-194.

Easley, David, and Maureen O'Hara, 1987, Price, trade size, and information in securities markets, Journal of Financial Economics 19, 69-90. 
Fama, Eugene F., and Kenneth R. French, 2001, Disappearing dividends: Changing firm characteristics or lower propensity to pay?, Journal of Financial Economics 60, 3-44.

Feenberg, Daniel, and Elizabeth Coutts, 1993, An introduction to the Taxsim model, Journal of Policy Analysis and Management 12, 189-194 (see also www.nber.org/ taxsim/mrates/mrates2.html).

Fenn, George W., and Nellie Liang, 2001, Corporate payout policy and managerial incentives, Journal of Financial Economics 60, 45-72.

Fuller, Kathleen, and Michael Goldstein, 2002, The ups and downs of dividend preference, University of Michigan working paper.

Glosten, Lawrence R. and Paul R. Milgrom, 1985, Bid, ask, and transaction prices in specialist market with heterogeneously informed traders, Journal of Financial Economics 14, 71100.

Graham, John R., 2001, Taxes and corporate finance: A review, Duke University working paper.

Graham, John R., and Campbell R. Harvey, 2001, The theory and practice of corporate finance: Evidence from the field, Journal of Financial Economics 60, 187-244.

Granger, Clive, and Paul Newbold, 1974, Spurious regressions in econometrics, Journal of Econometrics 2, 111-120.

Grinblatt, Mark, and Sheridan Titman, 1998, Financial Markets and Corporate Strategy, (Irwin/McGraw-Hill, Boston, MA).

Grullon, Gustavo, and Roni Michaely, 2002, Dividends, share repurchases, and the substitution hypothesis, Journal of Finance 57, 1649-1684.

Hall, Brian J., and Jeffrey B. Liebman, 1998, Are CEOs really paid like bureaucrats?, Quarterly Journal of Economics 63, 653-691.

Holmstrom, Bengt, and Steven N. Kaplan, 2001, Corporate governance and takeovers in the U.S.: Making sense of the 1980s and 1990s, Journal of Economic Perspectives 52, 121144.

Homer, Sidney, and Richard Sylla, 1996, A History of Interest Rates, (Rutgers U.P., New Brunswick, NJ).

Hubbard, Jeff, and Roni Michaely, 1997, Do investors ignore dividend taxation? A reexamination of the Citizens Utilities case, Journal of Financial and Quantitative Analysis 32, 117-135.

Jensen, Michael C., 1986, Agency costs of free cash flow, corporate finance and takeovers, American Economic Review 76, 323-329.

Jensen, Michael C., 1989, The eclipse of the public corporation, Harvard Business Review 67 (5), 61-74. 
John, Kose, and Joseph Williams, 1985, Dividends, dilution, and taxes: A signaling equilibrium, Journal of Finance 40, 1053-1070.

Jolls, Christine, 1998, The role of incentive compensation in explaining the stock-repurchase puzzle, Harvard University working paper.

Jones, Charles, 2002, A century of stock market liquidity and trading costs, Columbia University working paper.

Kahle, Kathleen M., 2002, When a buyback isn't a buyback: Open market repurchases and employee options, Journal of Financial Economics (forthcoming).

Kaplan, Steven N., 1997, The evolution of U.S. corporate governance: We are all Henry Kravis now, Journal of Private Equity 1, 7-14.

La Porta, Rafael, Florencio Lopez-de-Silanes, Andrei Shleifer, and Robert Vishny, 2000, Agency problems and dividend policies around the world, Journal of Finance 55, 1-33.

Lambert, Richard A., William N. Lanen, and David F. Larcker, 1989, Executive stock option plans and corporate dividend policy, Journal of Financial and Quantitative Analysis 24, 409-425.

Lewellen, Wilbur G., Kenneth L. Stanley, Ronald C. Lease, and Gary G. Schlarbaum, 1978, Some direct evidence on the dividend clientele phenomenon, Journal of Finance 33, 1385-1399.

Long, John B., 1978, The market valuation of cash dividends: A case to consider, Journal of Financial Economics 6, 235-264.

Malkiel, Burton G., 1990, A Random Walk Down Wall Street, (Norton, New York, NY).

Malkiel, Burton G., 1999, A Random Walk Down Wall Street, (Norton, New York, NY).

Marsh, Terry A., and Robert C. Merton, 1987, Dividend behavior for the aggregate stock market, Journal of Business 60, 1-40.

Miller, Merton H., and Franco Modigliani, 1961, Dividend policy, growth and the valuation of shares, Journal of Business 34, 411-433.

Miller, Merton H., and Kevin Rock, 1985, Dividend policy under asymmetric information, Journal of Finance 40, 1031-1051.

Miller, Merton H., and Myron Scholes, 1978, Dividends and taxes, Journal of Financial Economics 6, 333-364.

Modigliani, Franco, and Richard A. Cohn, 1979, Inflation, rational valuation and the market, Financial Analysts Journal 35, 24-44.

Newey, Whitney K, and Kenneth D. West, 1987, A simple, positive semi-definite, heteroskedasticity and autocorrelation consistent covariance matrix, Econometrica 55, 703-708. 
Poterba, James M., 1987, Tax policy and corporate saving, Brookings Papers on Economic Activity 2, 455-503.

Richardson, Matthew, and Eli Ofek, 2002, DotCom mania: The rise and fall of Internet stock prices, Journal of Finance (forthcoming).

Ross, Stephen A., The determinants of financial structure: The incentive-signalling approach, Bell Journal of Economics 8, 23-40.

Weisbenner, Scott J., 1999, Corporate share repurchases in the mid-1990s: What role do stock options play?, Federal Reserve Board working paper.

Yermack, David, 1995, Do corporations award CEO stock options effectively?, Journal of Financial Economics 39, 237-269. 
Figure 1. Disappearing dividends: Changing characteristics and changing propensity to pay. Panels A and B show the actual percent (solid) and expected percent (dash) of dividend payers in Compustat. Panels C and D show the propensity to pay dividends, i.e. the difference between the actual and expected percent. Panels $\mathrm{E}$ and $\mathrm{F}$ show changes in the propensity to pay dividends. Actual percent is the number of dividend payers divided by the number of firms in the sample that year. Expected percent is the expected percent of dividend payers based on prevailing sample characteristics. Following Fama and French (2001), and as described in Appendix 1, one set of results (Panels A, C, and E) estimates the expected percent of payers with a logit model that includes the NYSE market capitalization percentile, the market-to-book ratio, asset growth, and profitability. The other set (Panels B, D, and F) excludes market-to-book. The propensity to pay dividends PTP is the difference between the actual and expected percent. Detailed sample and variable definitions are in Appendix 1.

Panel A. Actual and expected percent payers

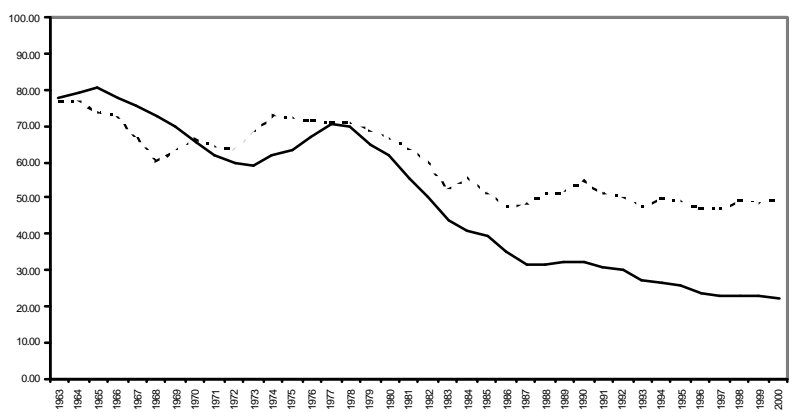

Panel C. The propensity to pay dividends

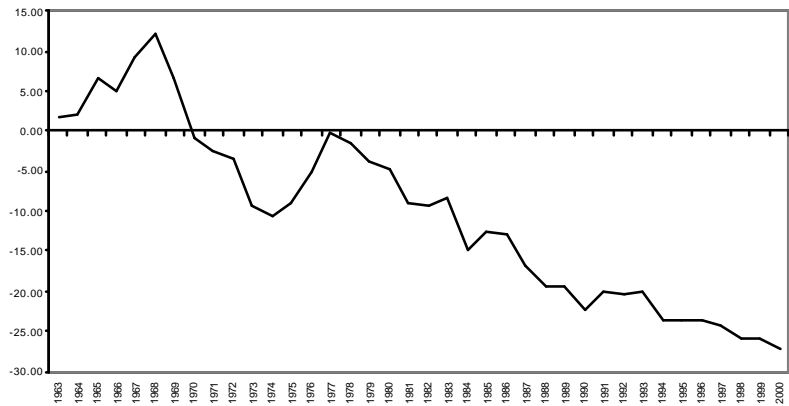

Panel E. Changes in the propensity to pay

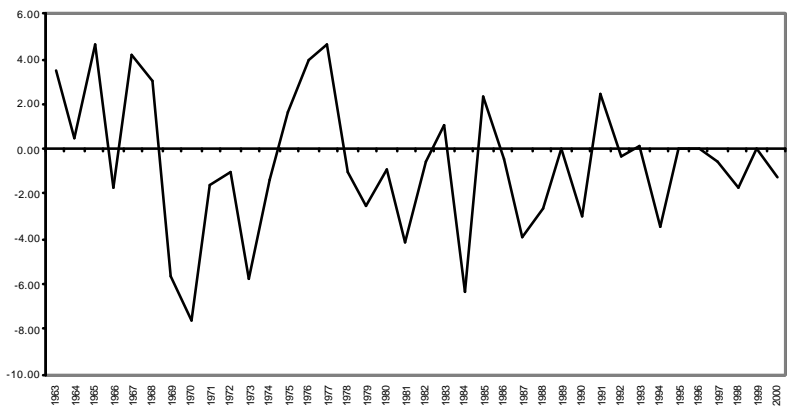

Panel B. Actual and expected percent payers (no $M / B$ )

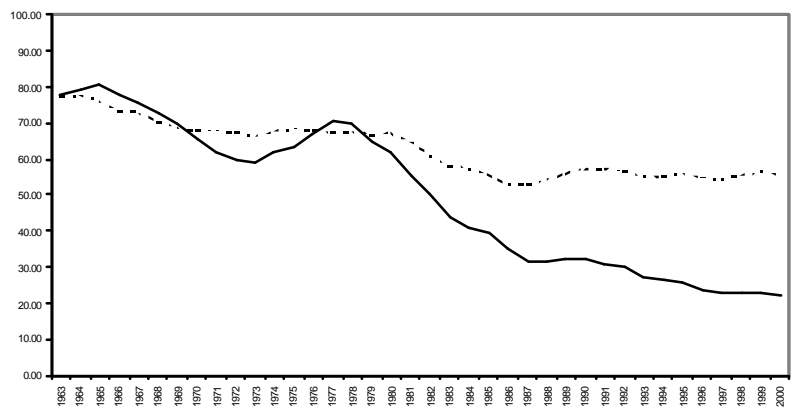

Panel D. The propensity to pay dividends (no $M / B$ )

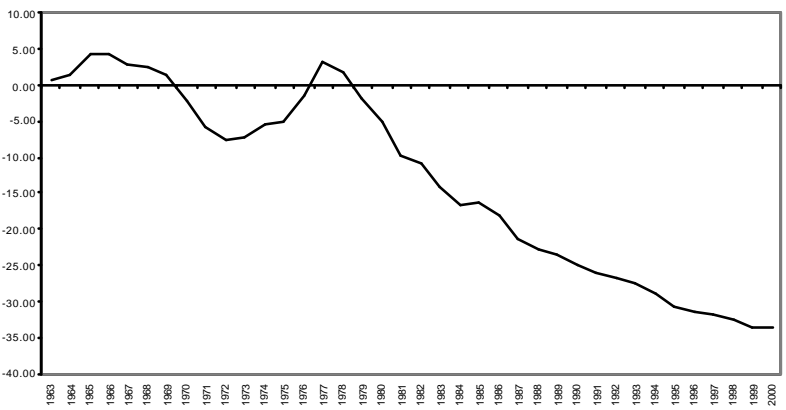

Panel F. Changes in the propensity to pay (no $M / B$ )

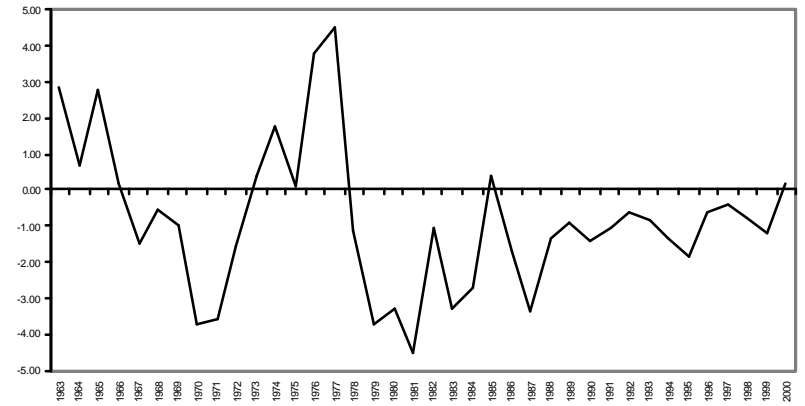


Figure 2. Time series influences on dividends. Panel A shows total one-way trading costs calculated as one-half the average percent bid-ask spread on Dow Jones Industrial Average stocks plus the average percent commission on round-lot NYSE transactions, both from Jones (2002). Panel B shows the average percent bid-ask spread on its own. Panel $\mathrm{C}$ shows the aggregate net asset value of equity mutual funds as a percent share of total NYSE/Amex/Nasdaq market capitalization. Panels D and E show the personal and corporate tax advantage of dividends (the percent difference in after-tax income received from dividends versus long-term capital gains) respectively. Panel F shows the mean value of option grants as a percent of mean total CEO compensation (options grants plus salary and bonus) from Hall and Liebman (1998). Panel G shows the percent of corporations (excluding financials and utilities) with an executive stock option plan in place from annual Conference Board surveys. Panel H shows the value-weighted dividend premium from Baker and Wurgler (2002) in percentage terms. Detailed variable definitions are in Appendix 1.

Panel A. One-way transaction costs

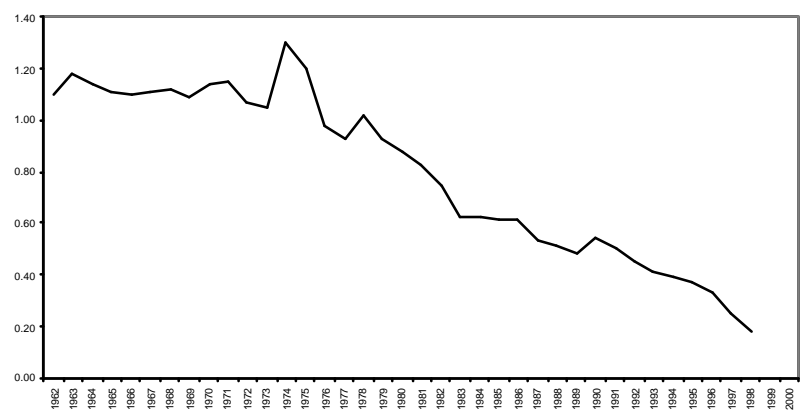

Panel C. Mutual fund share of assets

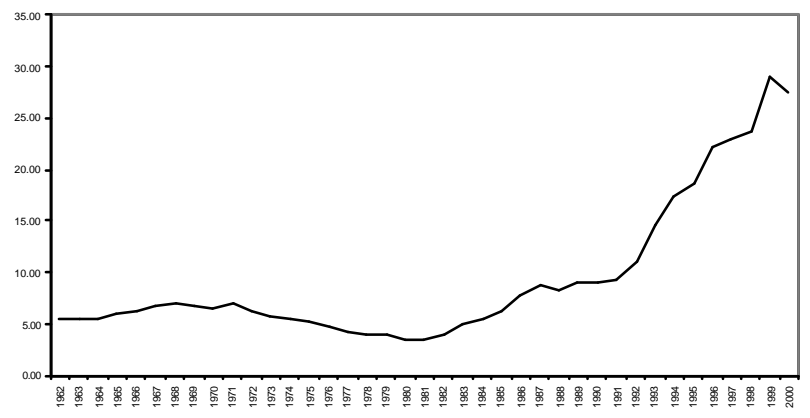

Panel E. Corporate tax advantage

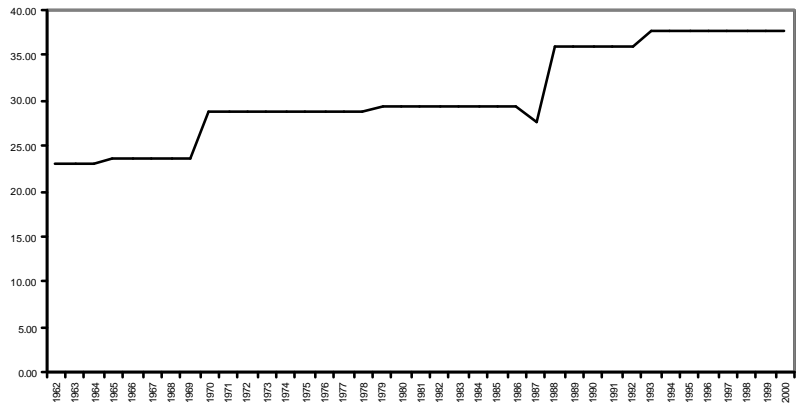

Panel G. Options plans

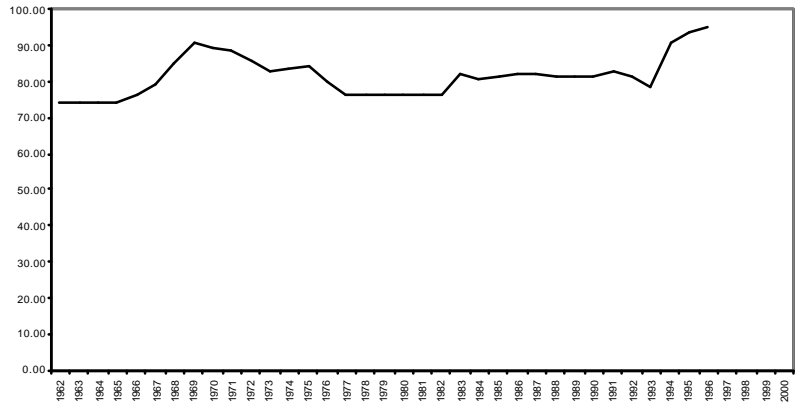

Panel B. Bid-ask spread

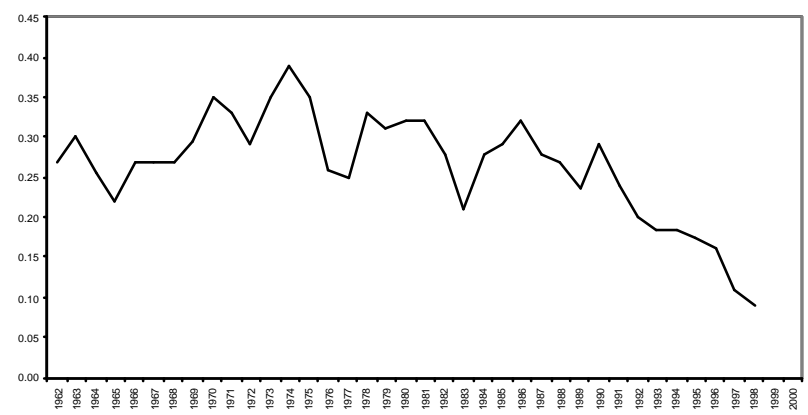

Panel D. Personal tax advantage

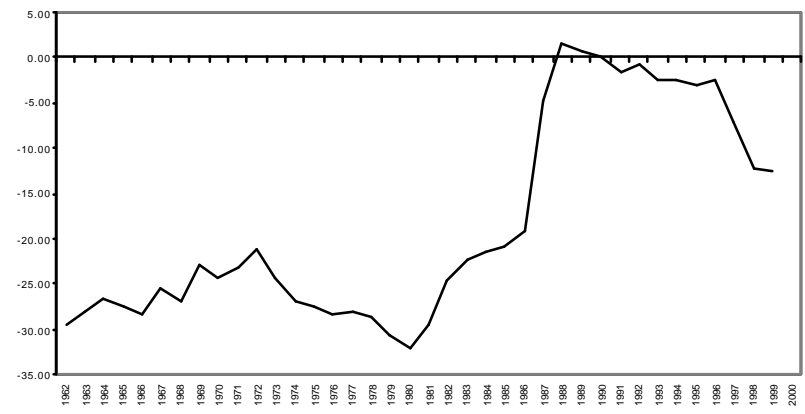

Panel F. Options share of CEO compensation

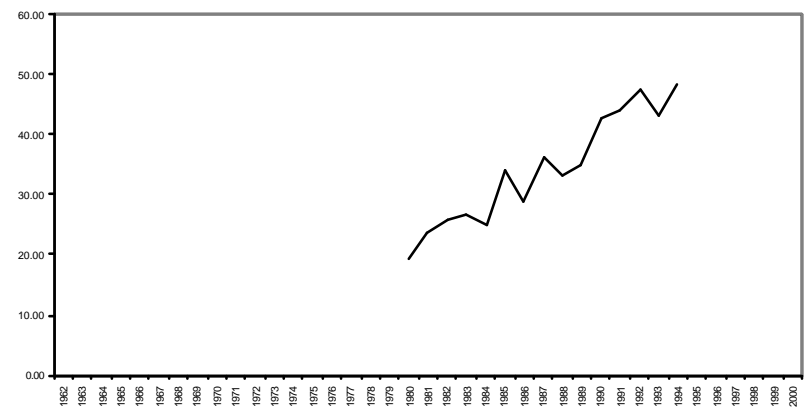

Panel H. Value-weighted dividend premium

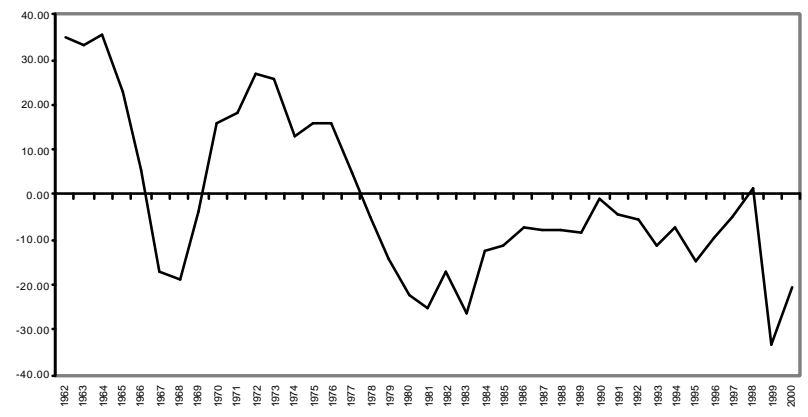


Table 1. Potential explanations for changes in the propensity to pay dividends. The table outlines explanations for time series fluctuations in the propensity to pay dividends that are motivated by the literature. The right column uses a declining propensity to pay as an illustrative example.

\begin{tabular}{|c|c|c|}
\hline Explanation & Theoretical basis & Mechanism behind declining propensity to pay \\
\hline Agency & $\begin{array}{l}\text { Easterbrook (1984), Jensen } \\
\text { (1986), La Porta, Lopez-de- } \\
\text { Silanes, Shleifer, and Vishny } \\
\text { (2000) }\end{array}$ & $\begin{array}{l}\text { Substitute corporate governance mechanisms have become relatively more effective, } \\
\text { reducing the need for dividends to control free cash flow problems. }\end{array}$ \\
\hline Information asymmetry & $\begin{array}{l}\text { Ross (1977), Bhattacharya } \\
\text { (1979), John and Williams } \\
\text { (1985), Miller and Rock (1985) }\end{array}$ & $\begin{array}{l}\text { Information asymmetries have disappeared or substitute signaling mechanisms have } \\
\text { become relatively more effective, reducing the need to signal inside information through } \\
\text { dividends. }\end{array}$ \\
\hline Stock options & $\begin{array}{l}\text { Lambert, Lanen, and Larcker } \\
\text { (1989) }\end{array}$ & $\begin{array}{l}\text { Managerial compensation in the form of stock options (without dividend protection) has } \\
\text { grown, leading to a bias against dividends. }\end{array}$ \\
\hline $\begin{array}{l}\text { Clientele equilibrium } \\
\text { Taxes } \\
\text { Investment constraints } \\
\text { Transaction costs }\end{array}$ & $\begin{array}{l}\text { Miller and Modigliani (1961), } \\
\text { Black and Scholes (1974), } \\
\text { Miller (1977), Miller (1986), } \\
\text { Allen, Bernardo, and Welch } \\
\text { (2001) }\end{array}$ & $\begin{array}{l}\text { Market imperfections that lead certain investors to rationally prefer dividends, such as } \\
\text { taxes, institutional investment constraints, or transaction costs, have changed over time so } \\
\text { as to shrink pro-dividend clienteles and thus dividends supplied in equilibrium. }\end{array}$ \\
\hline Catering & Baker and Wurgler (2002) & $\begin{array}{l}\text { Investor demand for nonpayers, driven by rational clientele considerations or sentiment, } \\
\text { has caused a stock market discount on payers and thus reduced the incentive to pay. }\end{array}$ \\
\hline Slow learning about taxes & None specific & $\begin{array}{l}\text { Managers have been persuaded of the tax disadvantage of dividends as governance } \\
\text { mechanisms have improved, or they are just slow learners. }\end{array}$ \\
\hline
\end{tabular}


Table 2. Summary of New York Times references to non-characteristics influences on dividends. Classification of references to non-characteristics based influences on dividends (as opposed to earnings or investment opportunities) that appear in the New York Times. Using Factiva, we identify 1,567 unique New York Times articles published between January 1, 1969 and December 31, 2001 that contain "dividend" or "dividends" at least twice in the abstract. From these 1,567 abstracts, we identify and read the full text of 103 articles that appear (on the basis of their abstract) to provide an analysis of dividend policy that goes beyond firm characteristics. From these 103 articles, we confirm and record 95 specific references to potential non-characteristics influences on dividends. We classify these references according to the explanation for changing propensity to pay dividends that they most closely invoke. (All references to clientele demands are classified under clientele equilibrium.) The middle column indicates the date around which references to each theme are concentrated. The second-to-last column shows the total number of references to each explanation or associated mechanism, and the last column shows the number that propose a link to dividend policy. Appendix 2 describes the article selection and reference classification procedure in detail. Table A lists the references themselves.

\begin{tabular}{|c|c|c|c|c|}
\hline Explanation & Mechanism & Date concentration & $\begin{array}{r}\text { Total } \\
\text { references }\end{array}$ & $\begin{array}{r}\text { Linked to } \\
\text { policy }\end{array}$ \\
\hline \multicolumn{2}{|l|}{ Agency } & 1971 & 1 & 1 \\
\hline \multicolumn{2}{|c|}{ Information asymmetry } & . & 0 & 0 \\
\hline \multicolumn{2}{|l|}{ Stock options } & $1999-2000$ & 2 & 2 \\
\hline
\end{tabular}

Clientele equilibrium

Taxes

\begin{tabular}{|c|c|c|c|c|}
\hline & Tax integration proposal & $1975-78$ & 8 & 0 \\
\hline & Withholding tax proposal & $1980-83$ & 21 & 0 \\
\hline & Personal tax changes & 1981,1986 & 6 & 5 \\
\hline & Intercorporate tax changes & 1995 & 1 & 1 \\
\hline Investment constraints & & 1977 & 2 & 1 \\
\hline \multirow[t]{3}{*}{ Transaction costs } & & . & 0 & 0 \\
\hline & Positive sentiment & 1975-77, 1984 & 11 & 5 \\
\hline & Negative sentiment & $1966-68,1995-2000$ & 10 & 7 \\
\hline \multirow[t]{5}{*}{ w learning about taxes } & & $1995-2000$ & 5 & 5 \\
\hline & Nixon dividend controls & $1971-73$ & 5 & 5 \\
\hline & Inflation hedge & $1974-77$ & 5 & 1 \\
\hline & DRIPs & $1975-78$ & 7 & 0 \\
\hline & Repurchases & $1995-2001$ & 11 & 11 \\
\hline al & & & 95 & 44 \\
\hline
\end{tabular}


Table 3. The propensity to pay and proxies for non-characteristics influences on dividends. The propensity to pay dividends is the difference between the actual and expected percentage of dividend payers. Following Fama and French (2001), the expected percentage of payers is estimated from logit regressions that take into account a set of characteristics that alternately does or does not include the market-to-book ratio. Transaction costs include total one-way trading costs (one-half the average percent bid-ask spread on Dow Jones Industrial Average stocks plus the average percent commission on round-lot NYSE transactions) and the average percent bid-ask spread on Dow Jones stocks, both from Jones (2002). Mutual funds data includes the aggregate net asset value of U.S. equity mutual funds (in current \$ billions) and as a percent share of total NYSE/Amex/Nasdaq market capitalization. The personal and corporate tax advantage of dividends is the after-tax income received from a dollar in dividends relative to a dollar in long-term capital gains. Options data includes the mean grant for CEOs in the Forbes compensation survey (in 1994 \$ thousands) and the mean grant as a share of the mean total option grants, salary, and bonus compensation for CEOs, both from Hall and Liebman (1998). The prevalence of option plans is the percent of corporations (excluding financials and utilities) with an executive stock option plan in place and taken from annual Conference Board surveys. The equal-weighted and value-weighted dividend premium are in percentage terms and taken from Baker and Wurgler (2002). Detailed definitions are in Appendix 1. 


\begin{tabular}{|c|c|c|c|c|c|c|c|c|c|c|c|c|c|}
\hline & \multicolumn{2}{|c|}{ Propensity to Pay } & \multicolumn{2}{|c|}{ Transaction Costs } & \multicolumn{2}{|c|}{ Mutual Funds } & \multicolumn{2}{|c|}{ Tax Advantage } & \multicolumn{3}{|c|}{ Options } & \multicolumn{2}{|c|}{ Dividend Premium } \\
\hline & M/B & No $\mathrm{M} / \mathrm{B}$ & $\begin{array}{c}\text { One- } \\
\text { way }\end{array}$ & Spread & NAV & Share & Personal & Corp & Grants & Share & Plans & EW & VW \\
\hline 1962 & -1.89 & -2.09 & 1.10 & 0.27 & 18.3 & 5.45 & -29.00 & 17.20 & & & 74.33 & 22.86 & 34.89 \\
\hline 1963 & 1.63 & 0.75 & 1.18 & 0.30 & 22.1 & 5.54 & -28.00 & 17.20 & & & 73.88 & 19.40 & 32.92 \\
\hline 1964 & 2.15 & 1.43 & 1.14 & 0.26 & 25.6 & 5.55 & -27.00 & 17.20 & & & 73.90 & 20.06 & 35.64 \\
\hline 1965 & 6.77 & 4.21 & 1.11 & 0.22 & 30.9 & 5.92 & -27.00 & 17.80 & & & 73.93 & 8.79 & 22.65 \\
\hline 1966 & 5.00 & 4.36 & 1.10 & 0.27 & 28.9 & 6.18 & -28.00 & 17.80 & & & 76.49 & 0.19 & 5.37 \\
\hline 1967 & 9.23 & 2.84 & 1.11 & 0.27 & 39.2 & 6.71 & -25.00 & 17.80 & & & 79.06 & -23.52 & -17.23 \\
\hline 1968 & 12.30 & 2.33 & 1.12 & 0.27 & 46.1 & 6.98 & -27.00 & 17.80 & & & 84.84 & -31.75 & -18.79 \\
\hline 1969 & 6.70 & 1.40 & 1.09 & 0.30 & 40.9 & 6.85 & -23.00 & 17.80 & & & 90.62 & -10.39 & -3.80 \\
\hline 1970 & -0.90 & -2.35 & 1.14 & 0.35 & 39.7 & 6.58 & -24.00 & 20.80 & & & 89.64 & 3.07 & 16.05 \\
\hline 1971 & -2.54 & -5.96 & 1.15 & 0.33 & 48.6 & 6.92 & -23.00 & 20.80 & & & 88.65 & 10.27 & 18.16 \\
\hline 1972 & -3.52 & -7.48 & 1.07 & 0.29 & 51.7 & 6.20 & -21.00 & 20.80 & & & 85.64 & 9.43 & 26.57 \\
\hline 1973 & -9.30 & -7.14 & 1.05 & 0.35 & 38.3 & 5.64 & -24.00 & 20.80 & & & 82.62 & 3.17 & 25.87 \\
\hline 1974 & -10.65 & -5.41 & 1.30 & 0.39 & 26.3 & 5.49 & -27.00 & 20.80 & & & 83.36 & 1.97 & 13.20 \\
\hline 1975 & -8.96 & -5.26 & 1.20 & 0.35 & 33.7 & 5.20 & -27.00 & 20.80 & & & 84.09 & -2.45 & 15.61 \\
\hline 1976 & -4.96 & -1.49 & 0.98 & 0.26 & 37.3 & 4.60 & -28.00 & 20.80 & & & 80.11 & -4.23 & 15.59 \\
\hline 1977 & -0.36 & 3.03 & 0.93 & 0.25 & 31.9 & 4.21 & -28.00 & 20.80 & & & 76.14 & -10.66 & 4.58 \\
\hline 1978 & -1.43 & 1.92 & 1.02 & 0.33 & 31.7 & 4.04 & -29.00 & 20.80 & & & 76.19 & -22.14 & -4.96 \\
\hline 1979 & -3.93 & -1.85 & 0.93 & 0.31 & 35.4 & 3.87 & -31.00 & 21.10 & & & 76.25 & -43.21 & -14.28 \\
\hline 1980 & -4.76 & -5.13 & 0.88 & 0.32 & 42.4 & 3.57 & -32.00 & 21.10 & 155.0 & 19.14 & 76.30 & -61.89 & -22.11 \\
\hline 1981 & -8.88 & -9.64 & 0.83 & 0.32 & 37.4 & 3.41 & -29.00 & 21.10 & 211.0 & 23.76 & 76.35 & -48.21 & -24.93 \\
\hline 1982 & -9.41 & -10.69 & 0.74 & 0.28 & 49.4 & 3.94 & -25.00 & 21.10 & 236.0 & 25.91 & 76.67 & -50.13 & -16.90 \\
\hline 1983 & -8.35 & -14.03 & 0.62 & 0.21 & 74.4 & 4.92 & -22.00 & 21.10 & 266.0 & 26.65 & 82.30 & -49.29 & -26.20 \\
\hline 1984 & -14.74 & -16.72 & 0.62 & 0.28 & 80.6 & 5.43 & -21.00 & 21.10 & 258.0 & 25.07 & 80.80 & -31.71 & -12.51 \\
\hline 1985 & -12.42 & -16.33 & 0.61 & 0.29 & 113.7 & 6.20 & -21.00 & 21.10 & 431.0 & 34.18 & 81.10 & -33.18 & -11.03 \\
\hline 1986 & -12.86 & -18.03 & 0.61 & 0.32 & 161.2 & 7.86 & -19.00 & 21.10 & 376.0 & 28.77 & 81.75 & -39.71 & -7.32 \\
\hline 1987 & -16.81 & -21.37 & 0.53 & 0.28 & 181.7 & 8.83 & -5.00 & 20.00 & 544.0 & 36.15 & 82.40 & -32.41 & -7.78 \\
\hline 1988 & -19.49 & -22.71 & 0.51 & 0.27 & 187.6 & 8.27 & 2.00 & 23.80 & 531.0 & 33.42 & 81.70 & -27.25 & -7.81 \\
\hline 1989 & -19.46 & -23.64 & 0.48 & 0.24 & 250.5 & 8.97 & 1.00 & 23.80 & 574.0 & 35.09 & 81.10 & -24.89 & -8.66 \\
\hline 1990 & -22.46 & -25.02 & 0.54 & 0.29 & 233.2 & 9.08 & 0.00 & 23.80 & 751.0 & 42.74 & 81.50 & -23.53 & -1.02 \\
\hline 1991 & -20.04 & -26.06 & 0.50 & 0.24 & 308.9 & 9.19 & -2.00 & 23.80 & 781.0 & 44.00 & 82.51 & -37.84 & -4.58 \\
\hline 1992 & -20.35 & -26.71 & 0.45 & 0.20 & 401.3 & 10.91 & -1.00 & 23.80 & 960.0 & 47.50 & 81.60 & -31.14 & -5.32 \\
\hline 1993 & -20.20 & -27.51 & 0.41 & 0.19 & 607.4 & 14.61 & -3.00 & 24.50 & 892.0 & 43.13 & 78.40 & -33.05 & -11.48 \\
\hline 1994 & -23.65 & -28.86 & 0.39 & 0.19 & 709.6 & 17.30 & -3.00 & 24.50 & $1,213.0$ & 48.42 & 90.40 & -27.56 & -7.47 \\
\hline 1995 & -23.69 & -30.71 & 0.37 & 0.18 & $1,024.9$ & 18.69 & -3.00 & 24.50 & & & 93.80 & -44.67 & -15.07 \\
\hline 1996 & -23.65 & -31.28 & 0.33 & 0.16 & $1,470.0$ & 22.05 & -3.00 & 24.50 & & & 95.00 & -35.55 & -9.43 \\
\hline 1997 & -24.26 & -31.67 & 0.25 & 0.11 & $2,018.7$ & 22.94 & -7.00 & 24.50 & & & & -22.95 & -4.82 \\
\hline 1998 & -26.01 & -32.44 & 0.18 & 0.09 & $2,506.2$ & 23.78 & -12.00 & 24.50 & & & & -21.84 & 1.44 \\
\hline 1999 & -26.03 & -33.63 & & & $3,376.7$ & 28.92 & -13.00 & 24.50 & & & & -74.90 & -33.17 \\
\hline 2000 & -27.26 & -33.47 & & & $3,226.9$ & 27.44 & & 24.50 & & & & -31.46 & -20.56 \\
\hline
\end{tabular}


Table 4. Statistics for non-characteristics influences on dividends. Correlations, autocorrelations, and unit root tests for non-characteristics time series influences on dividends. Transaction costs include total one-way trading costs (one-half the average percent bid-ask spread on Dow Jones Industrial Average stocks plus the average percent commission on round-lot NYSE transactions) and the average percent bid-ask spread on Dow Jones stocks, both from Jones (2002). The mutual fund share is the aggregate net asset value of U.S. equity mutual funds as a percent share of total NYSE/Amex/Nasdaq market capitalization. The personal and corporate tax advantage of dividends is the after-tax income received from a dollar in dividends relative to a dollar in long-term capital gains. The share of options grants as a percent share of total CEO compensation is the mean grant in the Forbes compensation survey divided by the mean total option grants, salary, and bonus from Hall and Liebman (1998). The prevalence of option plans is the percent of corporations (excluding financials and utilities) with an executive stock option plan in place and taken from annual Conference Board surveys. The equal-weighted and value-weighted dividend premium are in percentage terms and taken from Baker and Wurgler (2002). Detailed variable definitions are in Appendix 1. The first column shows the autocorrelation coefficient and its p-value in brackets, the next two columns show Dickey-Fuller test statistics (with a constant and without a trend term) and an approximate pvalue in brackets for levels and changes, and the remaining columns show the correlations among the variables their p-values in brackets.

\begin{tabular}{|c|c|c|c|c|c|c|c|c|c|c|c|c|}
\hline \multirow{3}{*}{\multicolumn{2}{|c|}{$\rho$}} & \multirow{3}{*}{$\begin{array}{r}\text { Levels } \\
\text { Unit } \\
\text { Root }\end{array}$} & \multirow{3}{*}{$\begin{array}{r}\text { Changes } \\
\text { Unit } \\
\text { Root }\end{array}$} & \multicolumn{5}{|c|}{ Mutual } & \multirow{2}{*}{\multicolumn{2}{|c|}{ Options }} & \multirow{2}{*}{\multicolumn{2}{|c|}{ Dividend Premium }} \\
\hline & & & & \multicolumn{2}{|c|}{ Transaction Costs } & \multirow{2}{*}{$\begin{array}{c}\text { Funds } \\
\text { Share }\end{array}$} & \multicolumn{2}{|c|}{ Tax Advantage } & & & & \\
\hline & & & & One-way & Spread & & Personal & Corp & Share & Plans & EW & VW \\
\hline \multicolumn{13}{|c|}{ Transaction Costs } \\
\hline One-way & $\begin{array}{r}0.97 \\
{[0.00]}\end{array}$ & $\begin{array}{r}0.49 \\
{[0.98]}\end{array}$ & $\begin{array}{r}-5.80 \\
{[0.00]}\end{array}$ & 1.00 & & & & & & & & \\
\hline Spread & $\begin{array}{r}0.79 \\
{[0.00]}\end{array}$ & $\begin{array}{r}-1.08 \\
{[0.72]}\end{array}$ & $\begin{array}{r}-6.44 \\
{[0.00]}\end{array}$ & $\begin{array}{r}0.74 \\
{[0.00]}\end{array}$ & 1.00 & & & & & & & \\
\hline \multicolumn{13}{|c|}{ Mutual Funds } \\
\hline Share & $\begin{array}{r}0.99 \\
{[0.00]}\end{array}$ & $\begin{array}{r}2.73 \\
{[1.00]}\end{array}$ & $\begin{array}{r}-4.42 \\
{[0.00]}\end{array}$ & $\begin{array}{r}-0.74 \\
{[0.00]}\end{array}$ & $\begin{array}{r}-0.82 \\
{[0.00]}\end{array}$ & 1.00 & & & & & & \\
\hline \multicolumn{13}{|c|}{ Tax Advantage } \\
\hline Personal & $\begin{array}{r}0.96 \\
{[0.00]}\end{array}$ & $\begin{array}{r}-1.11 \\
{[0.71]}\end{array}$ & $\begin{array}{r}-4.25 \\
{[0.00]}\end{array}$ & $\begin{array}{r}-0.82 \\
{[0.00]}\end{array}$ & $\begin{array}{r}-0.57 \\
{[0.00]}\end{array}$ & $\begin{array}{r}0.62 \\
{[0.00]}\end{array}$ & 1.00 & & & & & \\
\hline Corp & $\begin{array}{r}0.95 \\
{[0.00]}\end{array}$ & $\begin{array}{r}-1.23 \\
{[0.66]}\end{array}$ & $\begin{array}{r}-7.38 \\
{[0.00]}\end{array}$ & $\begin{array}{r}-0.85 \\
{[0.00]}\end{array}$ & $\begin{array}{r}-0.56 \\
{[0.00]}\end{array}$ & $\begin{array}{r}0.74 \\
{[0.00]}\end{array}$ & $\begin{array}{r}0.82 \\
{[0.00]}\end{array}$ & 1.00 & & & & \\
\hline \multicolumn{13}{|l|}{ Options } \\
\hline Share & $\begin{array}{r}0.87 \\
{[0.00]}\end{array}$ & $\begin{array}{r}-1.04 \\
{[0.74]}\end{array}$ & $\begin{array}{r}-7.65 \\
{[0.00]}\end{array}$ & $\begin{array}{r}-0.88 \\
{[0.00]}\end{array}$ & $\begin{array}{r}-0.69 \\
{[0.00]}\end{array}$ & $\begin{array}{r}0.87 \\
{[0.00]}\end{array}$ & $\begin{array}{r}0.86 \\
{[0.00]}\end{array}$ & $\begin{array}{r}0.80 \\
{[0.00]}\end{array}$ & 1.00 & & & \\
\hline Plans & $\begin{array}{r}0.84 \\
{[0.00]}\end{array}$ & $\begin{array}{r}-0.94 \\
{[0.78]}\end{array}$ & $\begin{array}{r}-4.83 \\
{[0.00]}\end{array}$ & $\begin{array}{r}-0.30 \\
{[0.08]}\end{array}$ & $\begin{array}{r}-0.19 \\
{[0.27]}\end{array}$ & $\begin{array}{r}0.66 \\
{[0.00]}\end{array}$ & $\begin{array}{r}0.45 \\
{[0.01]}\end{array}$ & $\begin{array}{r}0.46 \\
{[0.01]}\end{array}$ & $\begin{array}{r}0.63 \\
{[0.01]}\end{array}$ & 1.00 & & \\
\hline \multicolumn{13}{|c|}{ Dividend Premium } \\
\hline EW & $\begin{array}{r}0.78 \\
{[0.00]}\end{array}$ & $\begin{array}{r}-2.57 \\
{[0.10]}\end{array}$ & $\begin{array}{r}-6.57 \\
{[0.00]}\end{array}$ & $\begin{array}{r}0.62 \\
{[0.00]}\end{array}$ & $\begin{array}{r}0.24 \\
{[0.16]}\end{array}$ & $\begin{array}{r}-0.35 \\
{[0.03]}\end{array}$ & $\begin{array}{r}-0.34 \\
{[0.04]}\end{array}$ & $\begin{array}{r}-0.53 \\
{[0.00]}\end{array}$ & $\begin{array}{r}0.72 \\
{[0.00]}\end{array}$ & $\begin{array}{r}-0.13 \\
{[0.47]}\end{array}$ & 1.00 & \\
\hline VW & $\begin{array}{r}0.82 \\
{[0.00]} \\
\end{array}$ & $\begin{array}{r}-2.33 \\
{[0.16]} \\
\end{array}$ & $\begin{array}{r}-5.50 \\
{[0.00]}\end{array}$ & $\begin{array}{r}0.54 \\
{[0.00]}\end{array}$ & $\begin{array}{r}0.23 \\
{[0.17]} \\
\end{array}$ & $\begin{array}{r}-0.34 \\
{[0.03]}\end{array}$ & $\begin{array}{r}-0.30 \\
{[0.07]}\end{array}$ & $\begin{array}{r}-0.45 \\
{[0.00]}\end{array}$ & $\begin{array}{r}0.76 \\
{[0.00]} \\
\end{array}$ & $\begin{array}{r}-0.16 \\
{[0.36]}\end{array}$ & $\begin{array}{r}0.94 \\
{[0.00]} \\
\end{array}$ & 1.00 \\
\hline
\end{tabular}


Table 5. Determinants of the propensity to pay dividends. Univariate regressions of the propensity to pay dividends on non-characteristics influences. Total one-way trading costs (one-half the average percent bid-ask spread on Dow Jones Industrial Average stocks plus the average percent commission on round-lot NYSE transactions) and the average percent bid-ask spread on Dow Jones stocks are from Jones (2002). The mutual fund share is the aggregate net asset value of U.S. equity mutual funds as a percent share of total NYSE/Amex/Nasdaq market capitalization. The personal and corporate tax advantage of dividends is the after-tax income received from a dollar in dividends relative to a dollar in long-term capital gains. The share of options grants as a percent share of total CEO compensation is the mean grant in the Forbes compensation survey divided by the mean total option grants, salary, and bonus from Hall and Liebman (1998). The prevalence of option plans is the percent of corporations (excluding financials and utilities) with an executive stock option plan in place and taken from annual Conference Board surveys. The value-weighted dividend premium are in percentage terms and taken from Baker and Wurgler (2002). Detailed variable definitions are in Appendix 1. The first set of regressions runs the level of the propensity to pay on the contemporaneous level of the independent variable. The second set runs the change in the propensity to pay on the contemporaneous change. The third set runs the change in the propensity to pay on the lagged level. The levels of the independent variables are standardized to have unit variance. In Panel A, market-to-book is included as a firm characteristic in estimating the propensity to pay. In Panel B, it is excluded. T-statistics use standard errors that are robust to heteroskedasticity and serial correlation up to four lags.

\begin{tabular}{|c|c|c|c|c|c|c|c|c|c|c|c|c|c|}
\hline & \multirow[b]{3}{*}{ Sign } & \multicolumn{4}{|c|}{$P T P_{t}=a+b X_{t}+u_{t}$} & \multicolumn{4}{|c|}{$\Delta P T P_{t}=a+b \Delta X_{t}+v_{t}$} & \multicolumn{4}{|c|}{$\Delta P T P_{t}=a+b X_{t-1}+w_{t}$} \\
\hline & & \multicolumn{2}{|c|}{ 1963-2000 } & \multicolumn{2}{|c|}{$1963-1977$} & \multicolumn{2}{|c|}{$1963-2000$} & \multicolumn{2}{|c|}{ 1963-1977 } & \multicolumn{2}{|c|}{$1963-2000$} & \multicolumn{2}{|c|}{$1963-1977$} \\
\hline & & $\mathbf{b}$ & {$[\mathbf{t}]$} & $\mathbf{b}$ & {$[\mathbf{t}]$} & b & {$[\mathbf{t}]$} & $\mathbf{b}$ & {$[\mathbf{t}]$} & b & {$[\mathbf{t}]$} & $\mathbf{b}$ & {$[\mathbf{t}]$} \\
\hline & & \multicolumn{12}{|c|}{ Panel A. $M / B_{t}$ included } \\
\hline One-way transaction costs & + & 9.39 & {$[10.5]$} & -4.32 & {$[-0.6]$} & -2.40 & {$[-1.6]$} & -3.26 & {$[-2.2]$} & 0.42 & {$[0.8]$} & 2.14 & {$[0.7]$} \\
\hline Bid-ask spread & + & 5.27 & {$[3.3]$} & -6.64 & {$[-5.9]$} & -2.45 & {$[-4.1]$} & -3.68 & {$[-3.9]$} & 0.15 & {$[0.5]$} & -0.29 & {$[-0.4]$} \\
\hline Mutual fund share of assets & - & -7.80 & {$[-6.3]$} & 29.87 & {$[2.7]$} & 1.00 & {$[0.6]$} & 21.04 & {$[1.2]$} & -0.19 & {$[-0.6]$} & -25.17 & {$[-6.9]$} \\
\hline Personal tax advantage & + & -8.87 & {$[-5.5]$} & -2.90 & {$[-0.5]$} & -1.34 & {$[-1.1]$} & 2.95 & {$[0.6]$} & -0.29 & {$[-0.7]$} & -13.31 & {$[-7.7]$} \\
\hline Corporate tax advantage & + & -10.93 & {$[-12.5]$} & -10.78 & {$[-4.8]$} & -2.37 & {$[-1.4]$} & -7.68 & {$[-7.7]$} & -0.24 & {$[-0.4]$} & -0.36 & {$[-0.2]$} \\
\hline Options share of CEO compensation & - & -5.27 & {$[-9.5]$} & & & -0.28 & {$[-0.2]$} & & & 0.68 & {$[2.0]$} & & \\
\hline Option plans & - & -3.87 & {$[-1.5]$} & -1.35 & {$[-1.0]$} & -0.48 & {$[-0.5]$} & -0.63 & {$[-0.4]$} & -0.91 & {$[-1.3]$} & -2.42 & {$[-4.0]$} \\
\hline \multirow[t]{2}{*}{ VW dividend premium } & + & & & & & & & & & 1.04 & {$[2.4]$} & 1.19 & [1.7] \\
\hline & & \multicolumn{12}{|c|}{ Panel B. $M / B_{t}$ excluded } \\
\hline One-way transaction costs & + & 11.63 & {$[15.6]$} & -4.11 & {$[-1.0]$} & 0.39 & {$[0.2]$} & -1.30 & {$[-0.8]$} & 0.48 & {$[1.3]$} & -1.72 & {$[-1.1]$} \\
\hline Bid-ask spread & + & 7.68 & {$[5.2]$} & -4.49 & {$[-9.9]$} & -0.37 & {$[-0.9]$} & -1.03 & {$[-1.6]$} & -0.05 & {$[-0.2]$} & -0.49 & {$[-0.8]$} \\
\hline Mutual fund share of assets & - & -10.12 & {$[-6.7]$} & 0.95 & {$[0.1]$} & -1.42 & {$[-1.0]$} & -8.79 & {$[-0.9]$} & 0.04 & {$[0.1]$} & -20.46 & {$[-12.7]$} \\
\hline Personal tax advantage & + & -11.17 & {$[-6.5]$} & -11.57 & {$[-3.9]$} & -1.76 & {$[-3.3]$} & -2.79 & {$[-2.3]$} & -0.16 & {$[-0.4]$} & -5.93 & {$[-2.8]$} \\
\hline Corporate tax advantage & + & -12.58 & {$[-14.1]$} & -6.22 & {$[-4.2]$} & -0.77 & {$[-0.9]$} & -4.08 & {$[-4.8]$} & -0.28 & {$[-0.8]$} & 0.53 & {$[0.4]$} \\
\hline Options share of CEO compensation & - & -6.80 & {$[-8.8]$} & & & 0.02 & {$[0.0]$} & & & 0.58 & {$[2.3]$} & & \\
\hline Option plans & - & -5.61 & {$[-2.0]$} & -2.39 & {$[-2.7]$} & -0.99 & {$[-1.2]$} & -1.51 & {$[-1.2]$} & -0.26 & {$[-0.5]$} & -1.28 & {$[-2.6]$} \\
\hline VW dividend premium & + & & & & & & & & & 1.15 & {$[3.2]$} & 1.23 & [5.7] \\
\hline
\end{tabular}


Table 6. Explaining the post-1978 decline in the propensity to pay with option plans. Actual percent is the percentage of positive dividend payers in the Compustat sample. Expected percent is the expected percent of dividend payers based on prevailing sample characteristics. One set of results estimates the expected percent of payers with a logit model that includes the NYSE market capitalization percentile, the market-to-book ratio, asset growth, and profitability. The other set excludes market-to-book. The procedure follows Fama and French (2001) and is described in Appendix 1. The propensity to pay dividends PTP is the difference between the actual and expected percent. Expected PTP is the forecast value from a second stage regression of the level of the propensity to pay dividends on the percent of corporations (excluding financials and utilities) with an executive stock option plan in place, as reported by Conference Board surveys, for 1963-1977. The results of this regression are shown in Panel B. The level of the independent variable is standardized to have unit variance. T-statistics use standard errors that are robust to heteroskedasticity and serial correlation up to four lags. Detailed variable and sample definitions are in Appendix 1.

Panel A. Out of sample forecast of the propensity to pay dividends

\begin{tabular}{|c|c|c|c|c|c|c|c|c|c|}
\hline & \multirow[b]{2}{*}{$\begin{array}{r}\text { Actual } \\
\text { Percent }\end{array}$} & \multicolumn{2}{|c|}{$M / B_{t}$ included } & \multicolumn{2}{|c|}{$\begin{array}{l}\text { Option plans, } \\
M / B_{t} \text { included }\end{array}$} & \multicolumn{2}{|c|}{$M / B_{t}$ excluded } & \multicolumn{2}{|c|}{$\begin{array}{l}\text { Option plans, } \\
M / B_{t} \text { excluded }\end{array}$} \\
\hline & & $\begin{array}{r}\text { Expected } \\
\text { Percent } \\
\end{array}$ & PTP & $\begin{array}{r}\text { Expected } \\
\text { PTP }\end{array}$ & $\begin{array}{r}\text { PTP - } \\
\text { Expected } \\
\text { PTP }\end{array}$ & Expected & PTP & $\begin{array}{r}\text { Expected } \\
\text { PTP }\end{array}$ & $\begin{array}{r}\text { PTP - } \\
\text { Expected } \\
\text { PTP }\end{array}$ \\
\hline 1978 & 69.54 & 70.97 & -1.43 & 1.41 & -2.84 & 67.62 & 1.92 & 1.21 & 0.71 \\
\hline 1979 & 64.75 & 68.68 & -3.93 & 1.40 & -5.33 & 66.59 & -1.85 & 1.18 & -3.03 \\
\hline 1980 & 61.97 & 66.74 & -4.76 & 1.39 & -6.15 & 67.10 & -5.13 & 1.16 & -6.29 \\
\hline 1981 & 55.07 & 63.96 & -8.88 & 1.37 & -10.26 & 64.72 & -9.64 & 1.14 & -10.78 \\
\hline 1982 & 50.15 & 59.56 & -9.41 & 1.30 & -10.71 & 60.85 & -10.69 & 1.01 & -11.70 \\
\hline 1983 & 44.11 & 52.45 & -8.35 & -0.01 & -8.34 & 58.13 & -14.03 & -1.30 & -12.73 \\
\hline 1984 & 40.71 & 55.45 & -14.74 & 0.34 & -15.09 & 57.42 & -16.72 & -0.68 & -16.03 \\
\hline 1985 & 39.24 & 51.66 & -12.42 & 0.27 & -12.70 & 55.57 & -16.33 & -0.81 & -15.53 \\
\hline 1986 & 34.85 & 47.71 & -12.86 & 0.12 & -12.98 & 52.88 & -18.03 & -1.07 & -16.96 \\
\hline 1987 & 31.38 & 48.18 & -16.81 & -0.03 & -16.78 & 52.75 & -21.37 & -1.34 & -20.03 \\
\hline 1988 & 31.59 & 51.08 & -19.49 & 0.13 & -19.62 & 54.30 & -22.71 & -1.05 & -21.66 \\
\hline 1989 & 32.31 & 51.78 & -19.46 & 0.27 & -19.74 & 55.95 & -23.64 & -0.81 & -22.83 \\
\hline 1990 & 32.31 & 54.77 & -22.46 & 0.18 & -22.64 & 57.33 & -25.02 & -0.97 & -24.05 \\
\hline 1991 & 31.10 & 51.13 & -20.04 & -0.05 & -19.98 & 57.16 & -26.06 & -1.38 & -24.68 \\
\hline 1992 & 29.87 & 50.22 & -20.35 & 0.16 & -20.51 & 56.58 & -26.71 & -1.01 & -25.70 \\
\hline 1993 & 27.32 & 47.52 & -20.20 & 0.90 & -21.10 & 54.84 & -27.51 & 0.30 & -27.81 \\
\hline 1994 & 26.15 & 49.80 & -23.65 & -1.88 & -21.77 & 55.01 & -28.86 & -4.62 & -24.24 \\
\hline 1995 & 25.41 & 49.10 & -23.69 & -2.67 & -21.02 & 56.12 & -30.71 & -6.01 & -24.70 \\
\hline 1996 & 23.38 & 47.02 & -23.65 & -2.95 & -20.70 & 54.66 & -31.28 & -6.50 & -24.78 \\
\hline 1997 & 22.49 & 46.75 & -24.26 & & & 54.16 & -31.67 & & \\
\hline 1998 & 22.88 & 48.90 & -26.01 & & & 55.33 & -32.44 & & \\
\hline 1999 & 22.64 & 48.66 & -26.03 & & & 56.27 & -33.63 & & \\
\hline 2000 & 22.19 & 49.45 & -27.26 & & & 55.67 & -33.47 & & \\
\hline
\end{tabular}

Panel B. Regression of levels of the propensity to pay dividends on the prevalence of option plans

\begin{tabular}{|c|c|c|c|c|c|c|c|c|c|}
\hline & \multirow[b]{3}{*}{ Sign } & \multicolumn{4}{|c|}{$M / B_{t}$ included } & \multicolumn{4}{|c|}{$M / B_{t}$ excluded } \\
\hline & & \multicolumn{2}{|c|}{ 1963-2000 } & \multicolumn{2}{|c|}{ 1963-1977 } & \multicolumn{2}{|c|}{ 1963-2000 } & \multicolumn{2}{|c|}{ 1963-1977 } \\
\hline & & b & {$[\mathbf{t}]$} & b & {$[\mathbf{t}]$} & b & {$[\mathbf{t}]$} & b & [t] \\
\hline Option plans & - & -3.87 & {$[-1.5]$} & -1.35 & {$[-1.0]$} & -5.61 & {$[-2.0]$} & -2.39 & {$[-2.7]$} \\
\hline
\end{tabular}


Table 7. Explaining the post-1978 decline in the propensity to pay with the dividend premium. Actual percent is the percentage of positive dividend payers in the Compustat sample. Expected percent is the expected percent of dividend payers based on prevailing sample characteristics. One set of results estimates the expected percent of payers with a logit model that includes the NYSE market capitalization percentile, the market-to-book ratio, asset growth, and profitability. The other set excludes market-to-book. The procedure follows Fama and French (2001) and is described in Appendix 1. The propensity to pay dividends PTP is the difference between the actual and expected percent. Expected PTP is the forecast value from a second stage regression of the change in the propensity to pay dividends on the value-weighted dividend premium for 1963-1977. The results of this regression are shown in Panel B. The level of the independent variable is standardized to have unit variance. T-statistics use standard errors that are robust to heteroskedasticity and serial correlation up to four lags. Detailed variable and sample definitions are in Appendix 1.

Panel A. Out of sample forecast of the propensity to pay dividends

\begin{tabular}{|c|c|c|c|c|c|c|c|c|c|}
\hline & \multirow[b]{2}{*}{$\begin{array}{r}\text { Actual } \\
\text { Percent }\end{array}$} & \multicolumn{2}{|c|}{$M / B_{t}$ included } & \multicolumn{2}{|c|}{$\begin{array}{c}\text { Dividend Premium, } \\
M / B_{t} \text { included }\end{array}$} & \multicolumn{2}{|c|}{$M / B_{t}$ excluded } & \multicolumn{2}{|c|}{$\begin{array}{c}\text { Dividend Premium, } \\
M / B_{t} \text { excluded }\end{array}$} \\
\hline & & Expected & PTP & $\begin{array}{r}\text { Expected } \\
\text { PTP }\end{array}$ & $\begin{array}{r}\text { PTP - } \\
\text { Expected } \\
\text { PTP }\end{array}$ & Expected & PTP & $\begin{array}{r}\text { Expected } \\
\text { PTP }\end{array}$ & $\begin{array}{r}\text { PTP - } \\
\text { Expected } \\
\text { PTP }\end{array}$ \\
\hline 1978 & 69.54 & 70.97 & -1.43 & -0.57 & -0.86 & 67.62 & 1.92 & -0.36 & 2.28 \\
\hline 1979 & 64.75 & 68.68 & -3.93 & -1.78 & -2.16 & 66.59 & -1.85 & -1.37 & -0.47 \\
\hline 1980 & 61.97 & 66.74 & -4.76 & -3.59 & -1.17 & 67.10 & -5.13 & -3.02 & -2.10 \\
\hline 1981 & 55.07 & 63.96 & -8.88 & -5.93 & -2.96 & 64.72 & -9.64 & -5.21 & -4.44 \\
\hline 1982 & 50.15 & 59.56 & -9.41 & -8.44 & -0.97 & 60.85 & -10.69 & -7.58 & -3.11 \\
\hline 1983 & 44.11 & 52.45 & -8.35 & -10.43 & 2.09 & 58.13 & -14.03 & -9.41 & -4.62 \\
\hline 1984 & 40.71 & 55.45 & -14.74 & -13.03 & -1.71 & 57.42 & -16.72 & -11.87 & -4.84 \\
\hline 1985 & 39.24 & 51.66 & -12.42 & -14.73 & 2.31 & 55.57 & -16.33 & -13.40 & -2.93 \\
\hline 1986 & 34.85 & 47.71 & -12.86 & -16.34 & 3.48 & 52.88 & -18.03 & -14.83 & -3.20 \\
\hline 1987 & 31.38 & 48.18 & -16.81 & -17.70 & 0.89 & 52.75 & -21.37 & -16.00 & -5.37 \\
\hline 1988 & 31.59 & 51.08 & -19.49 & -19.08 & -0.41 & 54.30 & -22.71 & -17.21 & -5.50 \\
\hline 1989 & 32.31 & 51.78 & -19.46 & -20.47 & 1.01 & 55.95 & -23.64 & -18.41 & -5.22 \\
\hline 1990 & 32.31 & 54.77 & -22.46 & -21.92 & -0.54 & 57.33 & -25.02 & -19.68 & -5.34 \\
\hline 1991 & 31.10 & 51.13 & -20.04 & -22.86 & 2.83 & 57.16 & -26.06 & -20.42 & -5.64 \\
\hline 1992 & 29.87 & 50.22 & -20.35 & -24.04 & 3.69 & 56.58 & -26.71 & -21.41 & -5.30 \\
\hline 1993 & 27.32 & 47.52 & -20.20 & -25.27 & 5.07 & 54.84 & -27.51 & -22.45 & -5.07 \\
\hline 1994 & 26.15 & 49.80 & -23.65 & -26.90 & 3.25 & 55.01 & -28.86 & -23.90 & -4.96 \\
\hline 1995 & 25.41 & 49.10 & -23.69 & -28.27 & 4.58 & 56.12 & -30.71 & -25.09 & -5.62 \\
\hline 1996 & 23.38 & 47.02 & -23.65 & -30.14 & 6.49 & 54.66 & -31.28 & -26.79 & -4.49 \\
\hline 1997 & 22.49 & 46.75 & -24.26 & -31.63 & 7.37 & 54.16 & -31.67 & -28.11 & -3.57 \\
\hline 1998 & 22.88 & 48.90 & -26.01 & -32.83 & 6.81 & 55.33 & -32.44 & -29.11 & -3.33 \\
\hline 1999 & 22.64 & 48.66 & -26.03 & -33.61 & 7.58 & 56.27 & -33.63 & -29.69 & -3.94 \\
\hline 2000 & 22.19 & 49.45 & -27.26 & -36.67 & 9.41 & 55.67 & -33.47 & -32.62 & -0.85 \\
\hline
\end{tabular}

Panel B. Regression of changes in the propensity to pay dividends on the value-weighted dividend premium

\begin{tabular}{|c|c|c|c|c|c|c|c|c|c|}
\hline & \multirow[b]{3}{*}{ Sign } & \multicolumn{4}{|c|}{$M / B_{t}$ included } & \multicolumn{4}{|c|}{$M / B_{t}$ excluded } \\
\hline & & \multicolumn{2}{|c|}{$1963-2000$} & \multicolumn{2}{|c|}{ 1963-1977 } & \multicolumn{2}{|c|}{$1963-2000$} & \multicolumn{2}{|c|}{$1963-1977$} \\
\hline & & b & {$[\mathbf{t}]$} & b & {$[\mathbf{t}]$} & b & {$[\mathbf{t}]$} & b & {$[\mathbf{t}]$} \\
\hline VW dividend premium & + & 1.04 & {$[2.4]$} & 1.19 & [1.7] & 1.15 & [3.2] & 1.23 & [5.7] \\
\hline
\end{tabular}


Table 8. Changes in the propensity to pay dividends: Predicting returns, 1962-2000. Univariate regressions of future excess returns of dividend payers and nonpayers on the changes in the propensity to pay dividends. The dependent variable in Panel A is the difference in future real returns between dividend payers and nonpayers. The dependent variable in Panel B is future real return of dividend payers. The dependent variable in Panel $\mathrm{C}$ is the future real return of nonpayers. $r_{t+k}$ denotes returns in year $t+k$, and $R_{t+k}$ denotes cumulative returns from $t+1$ through $t+k$. The independent variable, changes in the propensity to pay dividends, is standardized to have unit variance. In the regressions reported in the left columns, the propensity to pay is estimated including the market-to-book ratio as a firm characteristic. In the right columns, it is not. We report OLS coefficients and bias-adjusted (BA) coefficients. Bootstrap p-values represent a two-tailed test of the null of no predictability.

\begin{tabular}{|c|c|c|c|c|c|c|c|c|c|}
\hline & \multirow[b]{2}{*}{$\mathbf{N}$} & \multicolumn{4}{|c|}{$M / B_{t}$ included } & \multicolumn{4}{|c|}{$M / B_{t}$ excluded } \\
\hline & & OLS & $\mathbf{B A}$ & [p-val] & $\mathbf{R}^{2}$ & OLS & $\mathbf{B A}$ & [p-val] & $\mathbf{R}^{2}$ \\
\hline & \multicolumn{9}{|c|}{ Panel A: Relative returns } \\
\hline$r_{D t+1}-r_{N D t+1}$ & 37 & -0.50 & -0.91 & {$[0.89]$} & 0.00 & -6.03 & -5.98 & {$[0.19]$} & 0.05 \\
\hline$r_{D t+2}-r_{N D t+2}$ & 36 & -7.11 & -7.39 & {$[0.06]$} & 0.08 & -15.05 & -14.88 & {$[0.00]$} & 0.34 \\
\hline$r_{D t+3}-r_{N D t+3}$ & 35 & -6.21 & -6.51 & {$[0.15]$} & 0.06 & -11.80 & -11.96 & {$[0.02]$} & 0.22 \\
\hline \multirow[t]{2}{*}{$R_{D t+3}-R_{N D t+3}$} & 35 & -14.37 & -16.10 & {$[0.34]$} & 0.10 & -32.68 & -32.56 & {$[0.04]$} & 0.47 \\
\hline & \multicolumn{9}{|c|}{ Panel B: Payer returns } \\
\hline$r_{D t+1}$ & 37 & -3.56 & -3.14 & {$[0.24]$} & 0.04 & -3.12 & -3.07 & {$[0.34]$} & 0.03 \\
\hline$r_{D t+2}$ & 36 & -3.19 & -3.05 & {$[0.32]$} & 0.03 & 0.45 & 0.24 & {$[0.90]$} & 0.00 \\
\hline$r_{D t+3}$ & 35 & 1.72 & 2.14 & {$[0.58]$} & 0.01 & 1.84 & 1.84 & {$[0.62]$} & 0.01 \\
\hline \multirow[t]{2}{*}{$R_{D t+3}$} & 35 & -5.13 & -4.45 & {$[0.55]$} & 0.04 & -0.89 & -1.02 & {$[0.92]$} & 0.00 \\
\hline & \multicolumn{9}{|c|}{ Panel C: Nonpayer returns } \\
\hline$r_{N D t+1}$ & 37 & -3.06 & -2.29 & {$[0.61]$} & 0.01 & 2.91 & 2.62 & {$[0.68]$} & 0.01 \\
\hline$r_{N D t+2}$ & 36 & 3.92 & 4.40 & {$[0.51]$} & 0.01 & 15.50 & 15.38 & {$[0.02]$} & 0.18 \\
\hline$r_{N D t+3}$ & 35 & 7.92 & 8.78 & {$[0.20]$} & 0.05 & 13.65 & 13.59 & {$[0.05]$} & 0.14 \\
\hline$R_{N D t+3}$ & 35 & 9.25 & 12.06 & {$[0.60]$} & 0.03 & 31.79 & 32.35 & {$[0.08]$} & 0.32 \\
\hline
\end{tabular}


Table 9. Summary. Summary of the ability of candidate explanations to address non-characteristics trends in dividend payment. Credit for references in media is given if the explanation (or its central mechanism) receives more than two references in the 1969-2001 sample of New York Times articles that involve dividends. Credit for addressing time trends in the propensity to pay dividends is given if a proxy variable for the explanation displays a visible trend in the appropriate direction over that period. Credit for the "out of sample" decline in the propensity to pay is given if at least one empirical proxy can explain the 1978-2000 decline in an empirical framework analogous to Fama and French (2001). Credit for addressing the remaining patterns is based on the discussion in the text. Two patterns are discussed there: that the recent decline in dividends occurs alongside an increase in the propensity to repurchase; and that changes in the propensity to pay dividends predict the relative stock returns of dividend payers and nonpayers.

\begin{tabular}{|c|c|c|c|c|c|c|c|c|}
\hline \multirow[b]{3}{*}{ Explanation } & \multicolumn{8}{|c|}{ Patterns addressed $(X=y e s, O=n o, .=$ untested or ambiguous $)$} \\
\hline & \multirow[b]{2}{*}{$\begin{array}{l}\text { References } \\
\text { in media }\end{array}$} & \multicolumn{5}{|c|}{ Time trends in propensity to pay dividends } & \multirow[b]{2}{*}{$\begin{array}{l}\text { Dividends } \\
\text { versus } \\
\text { repurchase }\end{array}$} & \multirow[b]{2}{*}{$\begin{array}{l}\text { Predict stock } \\
\text { returns }\end{array}$} \\
\hline & & $\begin{array}{l}\text { Up } \\
\text { 1963- } \\
1966 / 68\end{array}$ & $\begin{array}{l}\text { Down } \\
1967 / 69- \\
1972 / 74\end{array}$ & $\begin{array}{l}\text { Up } \\
1973 / 75- \\
1977\end{array}$ & $\begin{array}{l}\text { Down } \\
\text { 1978-2000 }\end{array}$ & $\begin{array}{l}\text { (Out of } \\
\text { sample) } \\
\text { Down } \\
\text { 1978-2000 }\end{array}$ & & \\
\hline Agency & $\mathrm{O}$ & . & . & . & . & . & $\mathrm{O}$ & $\mathrm{O}$ \\
\hline Information asymmetry & $\mathrm{O}$ & $\mathrm{O}$ & $\mathrm{O}$ & $\mathrm{X}^{\mathrm{a}}$ & $\mathrm{X}$ & $\mathrm{O}$ & $\mathrm{X}^{\mathrm{a}}$ & $\mathrm{O}$ \\
\hline Stock options & $\mathrm{O}$ & $\mathrm{O}^{\mathrm{b}}$ & $X^{c}$ & $\mathrm{X}$ & $X$ & $\mathrm{O}^{\mathrm{b}}$ & $X$ & $\mathrm{O}$ \\
\hline \multicolumn{9}{|l|}{ Clientele equilibrium } \\
\hline Taxes & $\mathrm{X}$ & $\mathrm{O}$ & $\mathrm{O}$ & $\mathrm{X}$ & $\mathrm{O}$ & $\mathrm{O}$ & $\mathrm{X}$ & $\mathrm{O}$ \\
\hline Transaction costs & $\mathrm{O}$ & $\mathrm{O}$ & $\mathrm{O}$ & $\mathrm{X}$ & $X^{d}$ & $\mathrm{O}$ & $X$ & $\mathrm{O}$ \\
\hline Investment constraints & $\mathrm{O}$ & . & . & . & . & . & $\mathrm{X}$ & $\mathrm{O}$ \\
\hline Catering & $X$ & $\mathrm{X}$ & $X^{c}$ & $X$ & $X$ & $X$ & $\mathrm{X}$ & $X$ \\
\hline Slow learners about taxes & $\mathrm{X}$ & $\mathrm{O}$ & . & $\mathrm{O}$ & . & . & $\mathrm{X}$ & $\mathrm{O}$ \\
\hline
\end{tabular}

\footnotetext{
${ }^{\mathrm{a}}$ Tax-based models, not investment-based models.

${ }^{\mathrm{b}}$ According to options plan proxy.

${ }^{c}$ Assuming that the Nixon-era dividend controls caused the decreasing propensity to pay between 1971 and $1972 / 74$.

${ }^{\mathrm{d}}$ According to mutual fund share proxy, not one-way cost or bid-ask spread proxy.
} 
Table A. New York Times references to non-characteristics influences on dividends. References to non-characteristics influences on dividends (as opposed to earnings or investment opportunities) that appear in the New York Times. Using Factiva, we identify 1,567 unique New York Times articles published between January 1, 1969 and December 31, 2001 that contain "dividend" or "dividends" at least twice in the abstract. From these 1,567 abstracts, we identify and read the full text of 103 articles that appear (on the basis of their abstract) to provide an analysis of dividend policy that goes beyond firm characteristics. From these 103 articles, we confirm and record 95 specific references to potential non-characteristics influences on dividends. Appendix 2 describes the article selection procedure. Below, we list these references in groups according to which explanation for changing propensity to pay dividends that they most closely invoke. (All references to clientele demands are classified under clientele equilibrium.) The first column counts the number of articles under each explanation. The third column lists, where appropriate, the specific mechanism invoked by the quotation. The fourth column indicates whether the quotation proposes a link between the explanation and dividend policy. The fifth column shows the date of the article and, where significant events sufficiently far from the date of the article are also referenced, dates of those events are listed in parentheses and counted as a separate reference as appropriate. The sixth column shows a summary quotation.

\begin{tabular}{|c|c|c|c|c|c|}
\hline $\mathbf{N}$ & Explanation & Mechanism & $\begin{array}{l}\text { Linked to } \\
\text { policy }\end{array}$ & Date & Quotation \\
\hline 1 & Agency & & Yes & $11 / 5 / 1971$ & $\begin{array}{l}\text { "... during the } 1960 \text { 's there was a great deal of criticism of business corporations } \\
\text { for hanging on to their earnings. ... The proclivity ... was attacked for a variety of } \\
\text { reasons, including ... the growth of executive compensation and perquisites ... and } \\
\text { the poor management decision-making that resulted from not having to meet a } \\
\text { market test for capital." }\end{array}$ \\
\hline
\end{tabular}

1 Stock options

2

1 Clientele equilibrium

Taxes

2

3
10/7/1999

$1 / 4 / 2000$

Tax integration proposal

No

$5 / 20 / 1977$

Tax integration

No proposal

Tax integration proposal

Tax integration proposal

Withholding tax
No market test for capital."

"Option holders benefit from price rises in the stocks of their companies, but not from dividends ... That provides an incentive for companies to hold down dividends and, instead, distribute money to shareholders by repurchasing stock."

"One explanation [for decline in percent of payers in S\&P] is ... stock options ... arguably providing an incentive to companies not to pay dividends."

"Prof. Leo Barnes ... favors an amendment to the tax law that would make all corporate cash dividends deductible ... The idea is rapidly gaining support.... chairman of NYSE came out in favor ... Treasury Secretary ... has also expressed his approval."

"Ironically ... as the business pleas [against double taxation of dividends] are finally getting a sympathetic hearing in the White House and the Congress, many prominent business executives are ... having some reservations ..."

7/11/1977 “... there have been changes on the tax front, and the promise of more in the wings, that have put dividends in brighter perspective ..."

“... neither proposal [elimination of double taxation of dividends or elimination of preferential treatment of capital gains] survived ... the President ... proceeded to scale down ... until the tax package disclosed a few weeks ago had been transformed into a pale shadow of his campaign promises."

"The Carter Administration announced today that it would propose legislation to subject interest and dividend payments to income-tax withholding ... legislation faces uncertain prospects on Capital Hill ... According to a 1979 I.R.S. study ... 9 to 16 percent of interest and dividend income was not reported ..." 
Table A. New York Times references to non-characteristics influences on dividends. Continued.

\begin{tabular}{|c|c|c|c|c|c|}
\hline $\mathbf{N}$ & Explanation & Mechanism & $\begin{array}{l}\text { Linked to } \\
\text { policy }\end{array}$ & Date & Quotation \\
\hline 6 & \multirow{4}{*}{$\begin{array}{l}\text { Clientele } \\
\text { equilibrium } \\
\text { Taxes } \\
\text { (continued) }\end{array}$} & \multirow[t]{2}{*}{ Withholding tax } & \multirow[t]{2}{*}{ No } & \multirow[t]{2}{*}{$3 / 23 / 1980$} & \multirow[t]{2}{*}{ [Discussion of withholding tax proposals; no policy shifts or revealing detail.] } \\
\hline & & & & & \\
\hline 7 & & Withholding tax & No & $4 / 29 / 1980$ & [Discussion of withholding tax proposals; no policy shifts or revealing detail.] \\
\hline 8 & & Withholding tax & No & $5 / 1 / 1980$ & $\begin{array}{l}\text { "The House Ways and Means Committee gave a chilly reception to day to } \\
\text { President Carter's proposal for a } 15 \text { percent withholding tax on dividends and } \\
\text { interest ..." }\end{array}$ \\
\hline 9 & & $\begin{array}{l}\text { Tax integration } \\
\text { proposal }\end{array}$ & No & 2/3/1978 & $\begin{array}{l}\text { "... chairman of the Ways and Means Committee, where tax legislation originates, } \\
\text { proposed [today] that in } 1979 \text { and } 1980 \text {, shareholders be permitted to take a tax } \\
\text { credit that would be 'generally equal to } 10 \text { percent of cash dividends' ... credit } \\
\text { would rise by } 2 \text { percentage points a year to } 20 \text { percent in } 1985 \text { and later." }\end{array}$ \\
\hline & & $\begin{array}{l}\text { Personal tax } \\
\text { changes }\end{array}$ & $\begin{array}{l}\text { Yes } \\
\text { Yes }\end{array}$ & $\begin{array}{l}2 / 15 / 1981 \\
(1978)\end{array}$ & $\begin{array}{l}\text { "Uncle Sam has contributed to the appeal of nondividend-paying stocks by cutting } \\
\text { the capital gains tax ... 'The } 1978 \text { tax cut bill made profits easier to take,' states } \\
\text { Standard \& Poor's. 'The top capital gains rate is now } 28 \text { percent; it had been } \\
49.125 \text { percent.'” }\end{array}$ \\
\hline 12 & & $\begin{array}{l}\text { Personal tax } \\
\text { changes }\end{array}$ & Yes & 9/27/1981 & $\begin{array}{l}\text { "... With the drop in the rates on unearned income [from a maximum of } 70 \text { percent } \\
\text { to a maximum of } 50 \text { percent as a result of the new tax law], there is even more of a } \\
\text { reason to pay a dividend." }\end{array}$ \\
\hline \multirow{2}{*}{$\begin{array}{l}13 \\
14\end{array}$} & & \multirow[t]{2}{*}{ Withholding tax } & No & $7 / 13 / 1982$ & \multirow{2}{*}{$\begin{array}{l}\text { "The provision in the Senate Finance Committee's tax bill authorizing the } \\
\text { withholding of income taxes on stock dividends and interest payments, once given } \\
\text { little chance of success, is gaining adherents ... Approval ...on the House floor } \\
\text { would represent a radical shift of sentiment from the mood of August 1980, when } \\
\text { the House defeated President Carter's request for interest and dividend withholding } \\
\text {.." }\end{array}$} \\
\hline & & & No & $(1980)$ & \\
\hline 15 & & Withholding tax & No & $3 / 3 / 1983$ & [Discussion of withholding tax proposals; no policy shifts or revealing detail.] \\
\hline 16 & & Withholding tax & No & $3 / 16 / 1983$ & [Discussion of withholding tax proposals; no policy shifts or revealing detail.] \\
\hline 17 & & Withholding tax & No & $3 / 17 / 1983$ & "The Senate fought to a standoff today on the question of tax withholding ..." \\
\hline 18 & & Withholding tax & No & 4/4/1983 & [Discussion of withholding tax proposals; no policy shifts or revealing detail.] \\
\hline 19 & & Withholding tax & No & $4 / 13 / 1983$ & [Discussion of withholding tax proposals; no policy shifts or revealing detail.] \\
\hline 20 & & Withholding tax & No & $4 / 16 / 1983$ & [Discussion of withholding tax proposals; no policy shifts or revealing detail.] \\
\hline 21 & & Withholding tax & No & $4 / 17 / 1983$ & [Discussion of withholding tax proposals; no policy shifts or revealing detail.] \\
\hline 22 & & Withholding tax & No & $4 / 20 / 1983$ & $\begin{array}{l}\text { "Senate Republicans reached a compromise agreement tonight to postpone for four } \\
\text { years, and perhaps indefinitely, the withholding of taxes from interest and dividend } \\
\text { income." }\end{array}$ \\
\hline
\end{tabular}


Table A. New York Times references to non-characteristics influences on dividends. Continued.

\begin{tabular}{|c|c|c|c|c|c|}
\hline $\mathbf{N}$ & Explanation & Mechanism & $\begin{array}{l}\text { Linked to } \\
\text { policy }\end{array}$ & Date & Quotation \\
\hline \multirow[t]{2}{*}{23} & $\begin{array}{l}\text { Clientele } \\
\text { equilibrium }\end{array}$ & Withholding tax & No & $4 / 28 / 1983$ & [Discussion of withholding tax proposals; no policy shifts or revealing detail.] \\
\hline & $\begin{array}{r}\text { Taxes } \\
\text { (continued) }\end{array}$ & & & & \\
\hline 24 & & Withholding tax & No & $5 / 5 / 1983$ & [Discussion of withholding tax proposals; no policy shifts or revealing detail.] \\
\hline 25 & & Withholding tax & No & $5 / 13 / 1983$ & [Discussion of withholding tax proposals; no policy shifts or revealing detail.] \\
\hline 26 & & Withholding tax & No & $5 / 18 / 1983$ & $\begin{array}{l}\text { "The House of Representatives voted overwhelmingly today to repeal the } \\
\text { withholding of taxes from dividends and interest payments." }\end{array}$ \\
\hline 27 & & Withholding tax & No & $6 / 14 / 1983$ & [Discussion of withholding tax proposals; no policy shifts or revealing detail.] \\
\hline 28 & & Withholding tax & No & $6 / 17 / 1983$ & "The Senate voted tonight to repeal a 1982 tax law that would require banks and \\
\hline 29 & & & No & (1982) & $\begin{array}{l}\text { corporations to withhold } 10 \text { percent of their interest and dividend payments } \\
\text { beginning July 1." }\end{array}$ \\
\hline 30 & & $\begin{array}{l}\text { Tax integration } \\
\text { proposal }\end{array}$ & No & $10 / 28 / 1985$ & $\begin{array}{l}\text { “..Ways and Means Committee rejected President Reagan's proposal that } \\
\text { companies be allowed, beginning in } 1987 \text {, to deduct } 10 \text { percent of the cost of } \\
\text { dividends they pay to shareholders. However, the panel decided to put the } 10 \\
\text { percent deduction in effect gradually, at the rate of one percentage point a year, so } \\
\text { that it would not be fully effective until 1997." }\end{array}$ \\
\hline 31 & & $\begin{array}{l}\text { Personal tax } \\
\text { changes }\end{array}$ & Yes & $6 / 1 / 1986$ & $\begin{array}{l}\text { "The Senate Finance Committee bill ... would reduce the effective tax rate on } \\
\text { dividends [from } 50 \text { to } 27 \text { percent], while raising the rate on capital gains [from } 20 \\
\text { to } 27 \text { percent].... Pressure will rise on corporations to increase dividend payouts } \\
\text {.." }\end{array}$ \\
\hline 32 & & $\begin{array}{l}\text { Personal tax } \\
\text { changes }\end{array}$ & No & $9 / 2 / 1986$ & $\begin{array}{l}\text { "Prospective changes in the nation's tax code promise to place the after-tax return } \\
\text { from dividend income virtually on a par, percentage-wise, with the return from } \\
\text { capital gains." }\end{array}$ \\
\hline 33 & & $\begin{array}{l}\text { Tax integration } \\
\text { proposal }\end{array}$ & No & $1 / 26 / 1989$ & $\begin{array}{l}\text { "The chairman of the Securities and Exchange Commission said today that he } \\
\text { favored the elimination of double taxation on dividends." }\end{array}$ \\
\hline 34 & & $\begin{array}{l}\text { Tax integration } \\
\text { proposal }\end{array}$ & No & $1 / 7 / 1992$ & $\begin{array}{l}\text { "The Treasury [today] proposed to 'integrate' corporate and shareholder levies so } \\
\text { earnings would no longer be taxed two or more times ..." }\end{array}$ \\
\hline 35 & & $\begin{array}{l}\text { Personal tax } \\
\text { changes }\end{array}$ & Yes & $1 / 4 / 1995$ & $\begin{array}{l}\text { "... many companies ... use share repurchases to get money to shareholders. That } \\
\text { is said to be better because dividends are taxed at ordinary income rates, while ... } \\
\text { share repurchases ... [are, for those who sell] taxed at a rate that now is lower for } \\
\text { many taxpayers and is likely to go down even further if the Republicans ... keep a } \\
\text { campaign promise." }\end{array}$ \\
\hline
\end{tabular}


Table A. New York Times references to non-characteristics influences on dividends. Continued.

\begin{tabular}{|c|c|c|c|c|c|}
\hline $\mathbf{N}$ & Explanation & Mechanism & $\begin{array}{l}\text { Linked to } \\
\text { policy }\end{array}$ & Date & Quotation \\
\hline 36 & $\begin{array}{l}\text { Clientele } \\
\text { equilibrium } \\
\text { Taxes } \\
\text { (continued) }\end{array}$ & $\begin{array}{l}\text { Intercorporate tax } \\
\text { changes }\end{array}$ & Yes & $12 / 21 / 1995$ & $\begin{array}{l}\text { "The Clinton Administration has proposed lowering that 'dividend received } \\
\text { deduction' [deduction on intercorporate dividends] to } 50 \text { percent [from } 70 \text { percent], } \\
\text { sending a chill through the market for both new and already issued preferred stocks } \\
\text {... Investors ... eagerly snapped up Citicorp's souped-up preferreds [which } \\
\text { increase the dividend if Congress approves the Administration's proposal]." }\end{array}$ \\
\hline 37 & $\begin{array}{l}\text { Clientele } \\
\text { equilibrium } \\
\text { Investment } \\
\text { constraints }\end{array}$ & & No & $2 / 14 / 1977$ & $\begin{array}{l}\text { "... pension reform legislation has brought a shift in thinking toward 'getting a } \\
\text { return' on investments." }\end{array}$ \\
\hline 38 & & & Yes & $1 / 4 / 2000$ & $\begin{array}{l}\text { "Dividends used to be a virtual requirement ... Some institutional investors were } \\
\text { barred from buying stocks that did not pay dividends." }\end{array}$ \\
\hline 1 & Catering & Positive sentiment & No & $3 / 16 / 1975$ & $\begin{array}{l}\text { "At the moment, the investment community seems to be more desirous of receiving } \\
\text { returns in the form of dividends rather than trying for capital appreciation." }\end{array}$ \\
\hline $\begin{array}{l}2 \\
3\end{array}$ & & $\begin{array}{l}\text { Positive sentiment } \\
\text { Negative sentiment }\end{array}$ & $\begin{array}{l}\text { No } \\
\text { No }\end{array}$ & $\begin{array}{l}\text { 9/13/1976 } \\
\text { (late } 1960 ’ s)\end{array}$ & $\begin{array}{l}\text { "During the speculative market of the late } 1960 \text { 's many brokers told customers that } \\
\text { it didn't matter whether a company paid a dividend - just so long as its stock kept } \\
\text { going up. ... Then came the bear market of } 1970 \text { to } 1975 . \text {... Faith in the growth } \\
\text { theory of investing diminished and when the stock market finally emerged from the } \\
\text { trough there was new respect for those old tried and true dividend-paying shares." }\end{array}$ \\
\hline 4 & & Positive sentiment & Yes & $11 / 7 / 1976$ & $\begin{array}{l}\text { "Thanks to ... [characteristics and] the rising yield-consciousness of stockholders, } \\
\text { corporations are fattening their dividend payouts. ... As investors became chary of } \\
\text { the stock market, they were less apt to count on future earnings growth ... and } \\
\text { more likely to return to the bird-in-the-hand rationale of cash dividends." }\end{array}$ \\
\hline 5 & & Positive sentiment & Yes & $2 / 14 / 1977$ & $\begin{array}{l}\text { "One reason for the strong upturn [in dividends], executives said, is the likelihood } \\
\text { that many companies will be making stock offerings before long to raise money. } \\
\text { Another reason, they said, is that many investors are displaying a growing interest } \\
\text { in stocks with high dividend yields." }\end{array}$ \\
\hline 6 & & Positive sentiment & No & $5 / 18 / 1977$ & $\begin{array}{l}\text { "After years of disappointment - particularly with low-yielding glamour stocks - } \\
\text { investors are emphasizing dividends in their stock selections." }\end{array}$ \\
\hline 7 & & Positive sentiment & Yes & $7 / 11 / 1977$ & $\begin{array}{l}\text { "Companies, looking to attract investors out of the bond market, and to interest } \\
\text { them in a resumption of new equity issues after years of virtually unremittant bear } \\
\text { market, are declaring, resuming and increasing payouts at a record rate. ... During } \\
\text { the April-May annual meeting season, the recurring shareholder cry was: 'Our } \\
\text { stock is way down in price - it might go up if you paid more.' ... Investors appear } \\
\text { to be more interested in current high yield with apparent safety than they are with } \\
\text { possible price appreciation which has not materialized over the last decade ..." }\end{array}$ \\
\hline 8 & & Positive sentiment & No & $11 / 8 / 1977$ & "Yields have become an increasingly important consideration for investors ..." \\
\hline
\end{tabular}


Table A. New York Times references to non-characteristics influences on dividends. Continued.

\begin{tabular}{|c|c|c|c|c|c|}
\hline $\mathbf{N}$ & Explanation & Mechanism & $\begin{array}{l}\text { Linked to } \\
\text { policy }\end{array}$ & Date & Quotation \\
\hline 9 & $\begin{array}{l}\text { Catering } \\
\text { (continued) }\end{array}$ & Positive sentiment & No & $11 / 9 / 1977$ & $\begin{array}{l}\text { "In a stock market in which income has become a prime consideration, the Phelps } \\
\text { Dodge development [dividend cut] was discouraging for investors and the stock } \\
\text { market." }\end{array}$ \\
\hline 10 & & Negative sentiment & No & $2 / 15 / 1981$ & $\begin{array}{l}\text { "... nondividend payers have become the Big Board's star performers in recent } \\
\text { years ... 'My sophisticated investors never ask me if a stock pays a cash dividend,' } \\
\text { says Mr. Schaeffer of Bache. 'They'd much rather have stock dividends than cash } \\
\text { dividends."” }\end{array}$ \\
\hline 11 & & Positive sentiment & No & $2 / 5 / 1984$ & $\begin{array}{l}\text { "Of all the reasons market analysts offer for why investors are building their cash } \\
\text { positions elsewhere, perhaps none is as pertinent as the fact that returns on } \\
\text { Treasury bills and bonds remain greater than the average income from stock } \\
\text { dividends." }\end{array}$ \\
\hline 12 & & Positive sentiment & Yes & $5 / 13 / 1984$ & $\begin{array}{l}\text { "... if interest rates continue to rise ... one way companies could continue to lure } \\
\text { investors to the stock market would be by increasing dividends." }\end{array}$ \\
\hline 13 & & Negative sentiment & Yes & $5 / 7 / 1995$ & $\begin{array}{l}\text { "These days, dividends are rising rapidly, but not as fast as stock prices ... perhaps } \\
\text { we are witnessing a sea change in investor attitudes. For a generation after the } 1929 \\
\text { crash ... it was taken for granted that stocks should pay a higher dividend yield } \\
\text { than bonds paid in interest. ... Most investors don't seem to be very interested in } \\
\text { dividends just now. ... Maybe dividends simply don't matter anymore." }\end{array}$ \\
\hline 14 & & Negative sentiment & Yes & $1 / 3 / 1997$ & $\begin{array}{l}\text { "In this buoyant stock market, companies have seen relatively little demand for } \\
\text { higher payouts from shareholders who, after all, have been seeking and getting } \\
\text { capital gains." }\end{array}$ \\
\hline 15 & & Negative sentiment & Yes & $1 / 6 / 1998$ & $\begin{array}{l}\text { "... investors seem to care less and less about dividends. And corporate boards, } \\
\text { seeing no need to part with cash to increase the stock prices of their companies, are } \\
\text { not doing so." }\end{array}$ \\
\hline 16 & & Negative sentiment & Yes & 10/7/1999 & "What is unusual is that the economy is doing so well even while companies are \\
\hline 17 & & Negative sentiment & Yes & $(1966-68)$ & growing more reluctant to raise their dividends ... the [last] time companies cut \\
\hline 18 & & Positive sentiment & Yes & (after 1968) & $\begin{array}{l}\text { back on dividend increases even as the economy continued to grow is ... from } \\
\text { August } 1966 \text { through March } 1968 \text {... the late-1960's market, memorably called the } \\
\text { 'the go-go years' ... bears more than a passing resemblance to this one. The stock } \\
\text { market had been going up steadily for the better part of two decades ... Mutual } \\
\text { fund managers became media stars ... a huge wave of mergers ... Dividends can go } \\
\text { so low because investors do not care much about them. It is capital gains that have } \\
\text { made them rich, and it is the pursuit of capital gains that drives stock investments } \\
\text { now. ... After 1968, as it became clear that capital losses were possible, investors } \\
\text { came to value dividends, and the pressure grew on companies to pay them." }\end{array}$ \\
\hline
\end{tabular}


Table A. New York Times references to non-characteristics influences on dividends. Continued.

\begin{tabular}{|c|c|c|c|c|c|}
\hline $\mathbf{N}$ & Explanation & Mechanism & $\begin{array}{l}\text { Linked to } \\
\text { policy }\end{array}$ & Date & Quotation \\
\hline $\begin{array}{l}19 \\
20\end{array}$ & $\begin{array}{l}\text { Catering } \\
\text { (continued) }\end{array}$ & Negative sentiment & $\begin{array}{l}\text { Yes } \\
\text { Yes }\end{array}$ & $\begin{array}{l}1 / 4 / 2000 \\
\text { (late } 1960 \text { 's) }\end{array}$ & $\begin{array}{l}\text { "A growing portion of corporate America appears to be concluding that dividends } \\
\text { are no longer needed to attract investors ... decline [in percent of payers in S\&P] } \\
\text { also reflects an investor attitude that puts little pressure on companies to make } \\
\text { payouts. ... The only similar trend occurred in the late 1960's, another time that } \\
\text { small technology companies were all the rage and the market for new issues was } \\
\text { red hot. A variety of reasons are given for the trend away from dividends, including } \\
\text { the tax disadvantages ... but that has always been true, and the effect presumably } \\
\text { should have been greater two decades ago, when tax rates were much higher ... } \\
\text { The most likely explanation ... would seem to be the most obvious. Investors, after } \\
\text { seeing year after year of huge capital gains, no longer see much of a need for } \\
\text { dividends as an assured return if the market declines ..." }\end{array}$ \\
\hline 21 & & Negative sentiment & No & $8 / 6 / 2000$ & $\begin{array}{l}\text { "Today's investors, fixated on making a quick buck, are likely to wonder how } \\
\text { anyone could ever have been interested in something so obviously irrelevant as } \\
\text { dividends." }\end{array}$ \\
\hline 1 & $\begin{array}{l}\text { Slow learning } \\
\text { about taxes }\end{array}$ & & Yes & $5 / 13 / 1984$ & $\begin{array}{l}\text { "... there is a growing sentiment that the role of dividends should be played down } \\
\text { and that cash payouts, because they are taxed more highly than long-term capital } \\
\text { gains, are actually a very costly way to compensate shareholders. ... despite the } \\
\text { argued drawbacks to dividends, specialists agree that groups of investors such as } \\
\text { retirees, wealthy individuals whose income is mostly sheltered, and nontax-paying } \\
\text { organizations, are most likely to prefer high-dividend stocks." }\end{array}$ \\
\hline 2 & & & Yes & $1 / 6 / 1998$ & $\begin{array}{l}\text { "The [newly] low payout ratio could be an indication that companies prefer to pay } \\
\text { cash to holders through share repurchases, which are taxed differently for holders." }\end{array}$ \\
\hline 3 & & & Yes & $1 / 24 / 1999$ & $\begin{array}{l}\text { "So why the [recent] corporate stinginess when it comes to payouts? One reason is } \\
\text { that companies know many investors simply aren't interested in dividends, because } \\
\text { they are well aware of the income taxes they will owe on such payouts." }\end{array}$ \\
\hline 4 & & & Yes & $1 / 4 / 2000$ & $\begin{array}{l}\text { "A variety of reasons are given for the trend away from dividends ... some } \\
\text { companies say they instead return money to shareholders by repurchasing shares, } \\
\text { allowing the sellers to pay lower capital gains tax rates on the money." }\end{array}$ \\
\hline 5 & & & Yes & $2 / 6 / 2000$ & $\begin{array}{l}\text { "... capital gains have grown as a share of all income, but dividends have not. The } \\
\text { results show tax policy at work. ... Federal tax law discourages dividends ..." }\end{array}$ \\
\hline 1 & Other & $\begin{array}{l}\text { Nixon controls on } \\
\text { dividends }\end{array}$ & Yes & $11 / 3 / 1971$ & $\begin{array}{l}\text { "A guideline limiting increases in corporation dividends to } 4 \text { per cent was } \\
\text { announced today by the committee regulating interest and dividends in the second } \\
\text { phase of President Nixon's economic stabilization program. ... freeze on dividends } \\
\text { has ... been voluntary. However, the administration put heavy pressure on } \\
\text { corporations to comply ..." }\end{array}$ \\
\hline
\end{tabular}


Table A. New York Times references to non-characteristics influences on dividends. Continued.

\begin{tabular}{|c|c|c|c|c|c|}
\hline $\mathbf{N}$ & Explanation & Mechanism & $\begin{array}{l}\text { Linked to } \\
\text { policy }\end{array}$ & Date & Quotation \\
\hline 2 & $\begin{array}{l}\text { Other } \\
\text { (continued) }\end{array}$ & $\begin{array}{l}\text { Nixon controls on } \\
\text { dividends }\end{array}$ & Yes & $11 / 5 / 1971$ & $\begin{array}{l}\text { "Phase One of the Administration's anti-inflation program slated to end next week } \\
\ldots \text { Phase One ... the President simply asked corporations to hold dividends at } \\
\text { existing levels; this the vast majority of corporations were delighted to do. For } \\
\text { Phase two ... requested corporations not to increase total dividends per share by } \\
\text { more than } 4 \text { per cent ..." }\end{array}$ \\
\hline 3 & & $\begin{array}{l}\text { Nixon controls on } \\
\text { dividends }\end{array}$ & Yes & $5 / 7 / 1972$ & [Discussion of dividend controls; no policy shifts or revealing detail.] \\
\hline 4 & & $\begin{array}{l}\text { Nixon controls on } \\
\text { dividends }\end{array}$ & Yes & $4 / 25 / 1973$ & [Discussion of dividend controls; no policy shifts or revealing detail.] \\
\hline 5 & & $\begin{array}{l}\text { Nixon controls on } \\
\text { dividends }\end{array}$ & Yes & $9 / 22 / 1973$ & [Discussion of dividend controls; no policy shifts or revealing detail.] \\
\hline 6 & & Inflation hedge & Yes & $4 / 30 / 1974$ & $\begin{array}{l}\text { "He [Consolidated Edison shareholder] said at the last stockholders' meeting [at } \\
\text { which Con Ed omitted its dividend] it was 'appalling' to see all of those old people } \\
\text { whose principal had been cut in half at that time while the dividend was static in } \\
\text { the face of 'runaway inflation."' }\end{array}$ \\
\hline 7 & & Inflation hedge & No & $2 / 24 / 1976$ & $\begin{array}{l}\text { "A number of investors asked analysts whether A.T.\&T. and corporations generally } \\
\text { are raising dividends sufficiently to keep pace with inflation." }\end{array}$ \\
\hline 8 & & Inflation hedge & No & $3 / 25 / 1977$ & [Discussion of dividends as a hedge against inflation.] \\
\hline 9 & & Inflation hedge & No & $9 / 1 / 1982$ & [Discussion of dividends as a hedge against inflation.] \\
\hline 10 & & Inflation hedge & No & $4 / 2 / 1994$ & [Discussion of dividends as a hedge against inflation.] \\
\hline 11 & & DRIPs & No & $3 / 4 / 1975$ & $\begin{array}{l}\text { "... recent ... renewed interest in dividend investment plans ... The latest versions } \\
\text { of these plans contain features ... all designed to make dividend reinvestment more } \\
\text { attractive to the average shareowner." }\end{array}$ \\
\hline 12 & & DRIPs & No & 9/17/1976 & $\begin{array}{l}\text { "About } 750 \text { corporations ... have begun dividend reinvestment programs in recent } \\
\text { years, and the list continues to grow." }\end{array}$ \\
\hline 13 & & DRIPs & No & $10 / 23 / 1976$ & $\begin{array}{l}\text { "The biggest such [dividend reinvestment] plan is that of the American Telephone } \\
\text { and Telegraph Company. ... The plan has proved so popular that it generates a } \\
\text { substantial amount of capital for the Bell System." }\end{array}$ \\
\hline 14 & & DRIPs & No & 9/4/1977 & $\begin{array}{l}\text { "Individual investors ... are accumulating shares by reinvesting their dividends at a } \\
\text { record clip." }\end{array}$ \\
\hline 15 & & DRIPs & No & $8 / 20 / 1978$ & $\begin{array}{l}\text { "... it is only in the last two to five years that the concept [of dividend reinvestment } \\
\text { plans] has caught on with corporate America. ... At present, it is estimated that } \\
\text { only some } 10 \text { to } 15 \text { percent of the eligible dividends are being reinvested." }\end{array}$ \\
\hline 16 & & DRIPs & No & $12 / 23 / 1978$ & [Discussion of features of dividend reinvestment plans.] \\
\hline 17 & & DRIPs & No & 8/7/1988 & [Discussion of features of dividend reinvestment plans.] \\
\hline
\end{tabular}


Table A. New York Times references to non-characteristics influences on dividends. Continued.

\begin{tabular}{|c|c|c|c|c|c|}
\hline $\mathbf{N}$ & Explanation & Mechanism & $\begin{array}{l}\text { Linked to } \\
\text { policy }\end{array}$ & Date & Quotation \\
\hline 18 & $\begin{array}{l}\text { Other } \\
\text { (continued) }\end{array}$ & Repurchases & Yes & $1 / 4 / 1995$ & $\begin{array}{l}\text { "Bulls ... note that many companies ... use share repurchases [instead of } \\
\text { dividends] to get money to shareholders." }\end{array}$ \\
\hline 19 & & Repurchases & Yes & $5 / 7 / 1995$ & $\begin{array}{l}\text { "The old record [for low aggregate dividend yield] was } 2.64 \text { percent set in August } \\
\text { 1987. Then, as now, Wall Street experts were reassuring about why you shouldn't } \\
\text { worry. The dividend yield figures were misleadingly low because they did not } \\
\text { include stock buybacks by companies, which were running at a high level ... } \\
\text { Buybacks are now running at an even higher level." }\end{array}$ \\
\hline 20 & & Repurchases & Yes & 1/3/1997 & $\begin{array}{l}\text { "... many companies argue that [they are not raising dividends because] they are } \\
\text { effectively returning money to shareholders by repurchasing their own shares." }\end{array}$ \\
\hline 21 & & Repurchases & Yes & $1 / 6 / 1998$ & $\begin{array}{l}\text { "The low payout ratio could be an indication that companies prefer to pay cash to } \\
\text { holders through share repurchases ..." }\end{array}$ \\
\hline 22 & & Repurchases & Yes & $10 / 7 / 1999$ & $\begin{array}{l}\text { "That [executive stock options] provides an incentive for companies to hold down } \\
\text { dividends and, instead, distribute money to shareholders by repurchasing stock. } \\
\text { Such stock repurchases are popular and many companies have borrowed money to } \\
\text { buy back stock." }\end{array}$ \\
\hline $\begin{array}{l}23 \\
24\end{array}$ & & Repurchases & $\begin{array}{l}\text { Yes } \\
\text { Yes }\end{array}$ & $\begin{array}{l}11 / 7 / 1999 \\
\text { (since mid- } \\
1980 \text { 's) }\end{array}$ & $\begin{array}{l}\text { "Many Wall Street analysts believe that this parsimony [decline in the number of } \\
\text { dividend payers] has been caused by the increasing popularity - since the mid- } \\
\text { 1980's - of companies' share repurchase programs. ... But Professors Fama and } \\
\text { French dismiss that view. They found that buyback plans have, almost exclusively, } \\
\text { been the province of dividend-paying large-cap companies." }\end{array}$ \\
\hline 25 & & Repurchases & Yes & $1 / 4 / 2000$ & $\begin{array}{l}\text { "A variety of reasons are given for the trend away from dividends ... some } \\
\text { companies say they instead return money to shareholders by repurchasing shares ... } \\
\text { but in many cases those purchases only offset the shares being issued to employees } \\
\text { who exercise options." }\end{array}$ \\
\hline $\begin{array}{l}26 \\
27\end{array}$ & & Repurchases & Yes & $\begin{array}{l}8 / 6 / 2000 \\
\text { (since early } \\
1980 \text { 's) }\end{array}$ & $\begin{array}{l}\text { "The prime suspect in the model's demise [the declining predictive power of the } \\
\text { dividend yield] has been corporate share repurchase programs. Such programs were } \\
\text { quite rare as recently as the early 1980's, but they have since grown so much ... } \\
\text { Therefore, the argument goes, record low dividends simply reflect a shift in how } \\
\text { corporations distribute their earnings ... but two finance professors, Eugene Fama } \\
\ldots \text { and Kenneth French ... contend that this argument does not completely solve } \\
\text { the mystery ... ". }\end{array}$ \\
\hline 28 & & Repurchases & No & $1 / 3 / 2001$ & $\begin{array}{l}\text { "... number of companies announcing plans to buy back their own shares has fallen } \\
\text { during the last several months ..." }\end{array}$ \\
\hline
\end{tabular}

